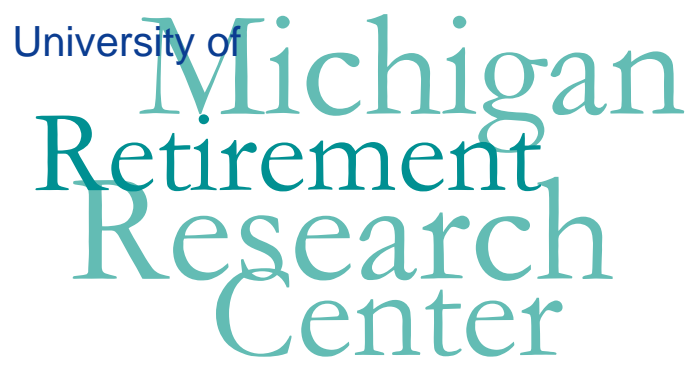

Working Paper WP 2005-104

\title{
Why Not Retire? The Time and Timing Costs of Market Work \\ Daniel S. Hamermesh
}

\begin{tabular}{|l|l|}
\hline $\mathrm{M}$ & $\mathrm{R}$ \\
\hline $\mathrm{R}$ & $\mathrm{C}$ \\
\hline
\end{tabular}$\quad$ Project \#: UM05-18 


\title{
Why Not Retire? The Time and Timing Costs of Market Work
}

\author{
Daniel S. Hamermesh \\ University of Texas at Austin
}

September 2005

\author{
Michigan Retirement Research Center \\ University of Michigan \\ P.O. Box 1248 \\ Ann Arbor, MI 48104 \\ http://www.mrrc.isr.umich.edu/ \\ (734) 615-0422
}

\section{Acknowledgements}

This work was supported by a grant from the Social Security Administration through the Michigan Retirement Research Center (Grant \# 10-P-98358-5). The findings and conclusions expressed are solely those of the author and do not represent the views of the Social Security Administration, any agency of the Federal government, or the Michigan Retirement Research Center.

\section{Regents of the University of Michigan}

David A. Brandon, Ann Arbor; Laurence B. Deitch, Bingham Farms; Olivia P. Maynard, Goodrich; Rebecca McGowan, Ann Arbor; Andrea Fischer Newman, Ann Arbor; Andrew C. Richner, Grosse Pointe Park; S. Martin Taylor, Gross Pointe Farms; Katherine E. White, Ann Arbor; Mary Sue Coleman, ex officio 


\title{
Why Not Retire? The Time and Timing Costs of Market Work
}

\author{
Daniel S. Hamermesh
}

\begin{abstract}
Retirement ages among older Americans have only recently begun to increase after their precipitous fifty-year decline. Early retirement may result from incentives provided by retirement systems; but it may also result from the rigidities imposed by market work schedules. Using the American Time Use Survey of 2003, I first examine whether additional market work is neutral with respect to the mix of non-market activities. The estimates indicate that there are fixed time costs of remaining in the labor market that alter the pattern of non-market activities, reducing leisure time and mostly increasing time devoted to household production. These costs impose a larger burden on households with lower full incomes, since wealthier households apparently purchase market substitutes that allow them to maintain the mix of non-market activities when they undertake market work. Market work also raises the set-up costs of switching among different non-market activities, thus raising the costs of generating utility-increasing variety. It also alters the daily distribution of a fixed amount of non-market activities, away from the distribution chosen when the constraint of a work schedule is not present. All these effects are mitigated by higher family income, presumably because higher-income people can purchase market substitutes that enable them to overcome the fixed time costs of market work.
\end{abstract}

\section{Authors’ Acknowledgements}

I am indebted to Leora Friedberg for a clever suggestion, Alain Jousten, Joseph Quinn and Thomas Wiseman for helpful comments and Rick Evans for excellent research assistance. The research reported herein was performed pursuant to a grant from the U.S. Social Security Administration (SSA) to the Michigan Retirement Research Center (MRRC) and a subcontract to the University of Texas. The opinions and conclusions are solely those of the author and should not be construed as representing the opinions or policy of SSA or any agency of the Federal Government or of the MRRC. 
The reason I am retiring fully is to have control of my schedule, so that I can travel, concentrate on big research projects, etc. Since it's scheduled at certain times, teaching always pushes other activities away. [Comment by astronomy professor]

\section{Introduction}

There is an immense literature in economics and other disciplines on the economic and demographic determinants of the labor supply of older workers (Lumsdaine and Mitchell, 1999). The distinction throughout has been between market work and all other activities, implicitly treating all nonmarket activities as homogeneous. That implicit assumption has partly been dictated by the amazing paucity of information on how older (and other) Americans divide their time outside the market. This assumption has led us to ignore the likelihood that older people and others do not view non-market activities as homogeneous (but see Kooreman and Kapteyn, 1987, and Biddle and Hamermesh, 1990). It is highly unlikely that such mundane activities as eating, washing or sleeping yield the same average satisfaction as leisure or sex, or that their opportunity costs are the same on average. For these reasons alone it is crucial to distinguish among these possible uses of time.

The importance of making distinctions among types of non-market activities seems especially great for older people. One of the most important problems facing the United States over the next few decades is the declining supply of skilled/experienced workers. Retirement ages have not increased, despite rapid increases in longevity even among older Americans (a 2.4 year increase among males age 65 between 1980 and 2002, a 1.1 year increase among women). Indeed, the labor-force participation rate of males $65+$ fell from 33.1 percent in 1960 to 16.3 percent in 1990 . Even in 2004 the rate was only 19.0 percent, despite the recent rise in the age of eligibility for full OASI benefits. With the baby-boom generation approaching retirement (and reaching it in the 2010s), the problem will be substantially exacerbated.

The evidence from studies of older workers' labor supply suggests that it is fairly inelastic with respect to wage increases. To encourage that supply, work opportunities may need to be re-structured to make them consistent with older Americans' desires to have their free time as unconstrained as possible, both in terms of what is done and when it is accomplished. That this is an increasingly important and increasingly recognized problem is made clear by both governmental attention and media reports. OECD 
Labor Ministers (2003) have emphasized that increased working-time flexibility can make an important contribution to lowering unemployment and raising employment rates more broadly. The problem has been discussed at length in Canada, where the data to analyze it exist but have not been exploited. ${ }^{1}$ Interestingly, a web-search for "phased retirement" shows that most of the "hits" are on universities' programs: Academics are one of the few groups whose employers' allow them the flexibility that meets the workers' preferences and the employers' demand for skill!

In this study I examine several aspects of the time allocation of older workers. First, and simplest, I present information on how older Americans use their time, how that allocation differs from that of younger people, and what determines these differences. This discussion is quite straightforward, and its emphasis on non-behavioral time accounting mirrors what constitutes the overwhelming amount of research on the allocation of time outside the market, including the only available examinations of older workers (Gauthier and Smeeding, 2003; Sayer et al, 2001). The bulk of the study focuses on answering the analytical question of how market work - the amount of time devoted to it and its timinggenerates an impediment to older Americans' optimization of the amount and sequencing of their nonmarket activities. Thus in the first part of the study I analyze how the decision to make the discrete choice of working in the market alters the mix of non-market activities. Since relatively few older persons work in the market, I infer the importance of this discrete choice from an analysis of the behavior of younger individuals.

The second part of this study concentrates on discovering when older people perform different activities and examining the determinants of this timing. An excellent theoretical study of timing (Winston, 1982) appeared over 20 years ago, and some empirical work has been done (Hamermesh, 1999, 2002) on the general population; but there has been no examination of how older people time their activities and what causes timing to differ. Given the likely importance of scheduling in employers'

\footnotetext{
${ }^{1}$ The Economist concludes a discussion of retirement ("Survey of Retirement," March 27, 2004, p. 10), "The best way to greet old age is surely to go off on that cruise and perhaps buy a holiday home in the sun-but then swap full-time for part-time work, with the regularity, companionship and cash that it brings." A recent survey of 1000 American workers suggests that many more wish to phase retirement than believe that their employers will allow them to do so (reported in Wall Street Journal, March 25, 2004, p. D3). Gustman and Steinmeier (2004) show that in the Health and Retirement Survey relatively few older workers believe that they will be able to reduce hours to the level that they wish as they age.
} 
demand for labor and the spillovers that these constraints may impose on people's schedules outside the labor market, discovering what scheduling looks like when the constraint of market work is no longer relevant would seem crucial for understanding how this instantaneous dimension may induce retirement.

\section{The Source of All Data: The American Time Use Survey, 2003}

The usual retrospective records that form the bases for most of the analysis of labor-force behavior in the economics and sociology literature ask individuals how many hours they worked in some recent time period, be it last week (as in the Current Population Survey) or last year (as in the Panel Study of Income Dynamics and the Census of Population). A number of data sets also provide information on how people divide their hours in a typical day (with no information on timing), or the most recent week or month, among a number of non-market activities that are either exhaustive (as in the Health and Retirement Survey) or partial (as in the PSID and the German Socioeconomic Panel), but that are not constrained to equal the total number of minutes or hours in the day or other time period. A time-budget survey gives respondents a daily log and asks them to indicate when they started each new activity and what that activity was. These are then coded into a variety of categories. The surveys have the virtue of immediacy and exhaustiveness, both of the time period covered and of the panoply of possible activities.

While there is a very long history of time-budget surveys in the United States (Sorokin and Berger, 1939), the U.S. lagged behind many other countries in developing these surveys from the 1970s through 2000. That changed in 2003 with the fielding of the American Time Use Survey. This data set provides time diaries from 1800 individuals each month, one person per household, for a total of nearly 21,000 in 2003. Because the respondents are recent members of the CPS panel, substantial information is also available on their work and earnings, on their families, and on other demographics. Of the respondents 4,679 are age 60 or over, so that the ATUS provides by far the largest number of time diaries ever completed by older Americans. Each year an additional 3,000 or so older Americans will be providing time diaries. ${ }^{2}$

Most time-budget surveys provide information on at least 50 categories of activity, so that both for ease of analysis and ease of presentation the user is usually obliged to aggregate the data into a

\footnotetext{
${ }^{2}$ See Hamermesh et al (2005) for a description of the survey, and Horrigan and Herz (2005) for details on its origins and construction.
} 
reasonably smaller number of useful categories. That choice is inherently arbitrary. Here I take two approaches to aggregating the 406 individual activities reported in the ATUS. At the highest level of aggregation I divide activities into four groups: 1) Market work; 2) Secondary activities, those for which the individual might have purchased market substitutes. These activities satisfy Reid's (1934) third-party rule defining household production. 2) Tertiary activities, those that one must perform for oneself but that are essentially personal maintenance; and 4) Leisure. Also included is a category "Other," which accounts for a few miscellaneous activities and those few minutes in some respondents' days for which no activity is recorded. At a slightly less aggregated level I also break secondary activities down into household work and shopping, and child and other care, including volunteering; and I disaggregate tertiary activities into sleeping, eating and drinking, and personal care.

Table 1 presents the average time allocations by age in the lower-level aggregates listed above. I present these separately for individuals below age 55, then by five-year age group. Of course, the biggest change with age is the decline in market activity. As is well known, and as the time diaries show, the major declines begin at age 60 . What is interesting is how the time that is freed up, roughly 180 minutes among 65-69 year-olds compared to 55-59 year-olds on a typical day. There is essentially no change in the time devoted to personal care. Household production increases by about 30 minutes, sleeping increases by 25 minutes, and time devoted to eating and drinking increases by 10 minutes across this 10 year age difference. Of the extra three hours that become available, the overwhelming majority, nearly two full hours, are devoted to additional leisure time. Not only is this the largest absolute change generated by the decline in the time devoted to market work in these aggregates, it is also by far the largest in percentage terms. Clearly, among the activities that might be crowded out by market work, leisure is the main one.

The estimates shown in Table 1 do not account for other demographic differences that might be generating the apparent age differences in time allocations. To resolve this potential difficulty, in Table 2 I present least-squares estimates of the determinants of time spent in each of the lower-level aggregates of 
activities. ${ }^{3}$ Only people ages 60 and over are included, and the excluded age indicator is for people 6064. If anything, the estimates strengthen the conclusion from Table 1 that most of the decline in market work that occurs after age 60 is made up by an increase in leisure. Accounting for demographic differences (race, ethnicity, gender and marital status), roughly 2 hours of the $2-1 / 2$ hour decline in average daily hours of market work between ages 60-64 and ages 75+ are taken up by a gain in leisure. Indeed, while the other changes are all statistically significant, only the half-hour increase in sleep time is economically important.

\section{A Model of the Fixed Time Costs of Market Work}

Why does an increase in leisure time represent the overwhelming use of the time that is freed up as older people reduce their hours of market? That is, why do those who are active in the labor market apparently wish to expand leisure time so much more than other non-market activities as soon as they have the opportunity? Is this a continuous response; or are there lumpy time costs of market work that have differential impacts on the amounts of time devoted to other activities, impacts whose effects are removed when an individual ceases market work?

To examine these issues consider the simplest possible formulation, in which there are three uses of time: $\mathrm{T}_{\mathrm{M}}$, market work; $\mathrm{T}_{\mathrm{ST}}$, secondary and tertiary activities; and $\mathrm{T}_{\mathrm{L}}$, leisure. Assume that the individual is single and faces a parametric wage $\mathrm{w}$ and unearned income I. Each minute devoted to market work must necessarily reduce the time devoted to other activities by one minute. This is obviously true in reality, but it is a requirement imposed by time-budget data (although by no means necessarily by retrospective subjective data). There may be fixed time costs of market work such that the effectiveness of the remaining time devoted to ST and L is reduced by constant fractions $\mu_{\mathrm{ST}}$ and $\mu_{\mathrm{L}}$ when even a small amount of market work is undertaken. ${ }^{4}$ The fixed time costs might, for example, stem from a need to hurry in one's other activities (e.g., racing through one's breakfast in order to get to work on

\footnotetext{
${ }^{3}$ One minus the sum of the estimated coefficients in each column will equal the impact of the variable on time spent that is accounted for by the few miscellaneous activities. All of these latter effects are small and statistically insignificantly different from zero.

${ }^{4}$ These differ from the possible fixed money costs of work discussed by Cogan (1981) and assumed to be absent here.
} 
time, foregoing watching The Tonight Show in order to be rested for work the next morning). They might induce workers to engage in a different, and perhaps less satisfying mix of other activities (tying a necktie as personal care rather than enjoying sex or a relaxing bath, work-related socializing with colleagues or clients rather than playing a game of tennis with a close personal friend).

Assuming no saving, the person's utility is:

$$
\mathrm{U}\left(\mathrm{I}, \mathrm{T}_{\mathrm{ST}}, \mathrm{T}_{\mathrm{L}}\right), \quad \text { if } \mathrm{T}_{\mathrm{M}}=0
$$

and

$$
\mathrm{U}\left(\mathrm{I}+\mathrm{w}\left[24-\mathrm{T}_{\mathrm{ST}}-\mathrm{T}_{\mathrm{L}}\right], \mu_{\mathrm{ST}} \mathrm{T}_{\mathrm{ST}}, \mu_{\mathrm{L}} \mathrm{T}_{\mathrm{L}}\right), 0<\mu_{\mathrm{ST}}, \mu_{\mathrm{L}}<1, \text { if } \mathrm{T}_{\mathrm{M}}>0 .^{5}
$$

The utility cost of the first moment of market work, the fixed (utility) cost of market work, is then:

$$
\mathrm{V}=\mathrm{U}\left(\mathrm{I}, \mathrm{T}_{\mathrm{ST}}, \mathrm{T}_{\mathrm{L}}\right)-\mathrm{U}\left(\mathrm{I}, \mu_{\mathrm{ST}} \mathrm{T}_{\mathrm{ST}}, \mu_{\mathrm{L}} \mathrm{T}_{\mathrm{L}}\right)>0 .
$$

The individual maximizes utility, choosing maximizing time allocations $\mathrm{T}_{\mathrm{ST}}^{*}>0$ and $\mathrm{T}_{\mathrm{L}}{ }_{\mathrm{L}}>0$, and $\mathrm{T}_{\mathrm{M}} \geq 0$. If $\mathrm{T}_{\mathrm{M}}^{*}=0$ is maximizing:

$$
\mathrm{U}_{2} / \mathrm{U}_{3}=1
$$

if $\mathrm{T}_{\mathrm{M}}^{*}>0$ is maximizing:

$$
\mathrm{U}_{2} / \mathrm{U}_{3}=\mu_{\mathrm{L}} / \mu_{\mathrm{ST}}
$$

Only if:

$$
\mathrm{U}\left(\mathrm{I}+\mathrm{w}\left[24-\mathrm{T}_{\mathrm{ST}}^{*}-\mathrm{T}_{\mathrm{L}}^{*}\right], \mu_{\mathrm{ST}} \mathrm{T}_{\mathrm{ST}}^{*}, \mu_{\mathrm{L}} \mathrm{T}_{\mathrm{L}}^{*}\right)-\mathrm{U}\left(\mathrm{I}, \mathrm{T}_{\mathrm{ST}}, \mathrm{T}_{\mathrm{L}}\right)>\mathrm{V},
$$

for some combination of $\mathrm{T}^{*}{ }_{\mathrm{ST}}$ and $\mathrm{T}_{\mathrm{L}}{ }_{\mathrm{L}}$ does the individual supply positive hours of market work. If s/he does, and if the effective relative price of secondary/tertiary activities and leisure changes from unity to $\mu_{\mathrm{ST}} / \mu_{\mathrm{L}} \neq 1$, we will observe that the very first minute of market work alters the relative amounts of secondary/tertiary and leisure activities chosen. Thus while we cannot observe the existence of fixed time costs of work directly, we can observe whether their impact on the individual's allocation of time across other activities is neutral by observing how patterns of time use change in response to an initial moment of market work.

Unlike prices of market goods, the relative price change generated by the existence of fixed time costs of work can differ among individuals. Those who have higher I might use their additional unearned

\footnotetext{
${ }^{5}$ In this formalization I thus ignore Becker's (1965) notion of substituting goods for time, although I bring it in later
} in the discussion of the role of differences in unearned income. 
income to substitute purchased goods and/or services for those secondary activities whose price has risen because the individual has chosen to bear the fixed time costs of working. One benefit of additional unearned income may be to lower the impact of the fixed time costs of work. ${ }^{6}$

This discussion suggests that there may be discontinuous changes in the allocation of individuals' time when they do not engage in market work. It also implies that these potential effects will differ depending on the income in the household to which the worker belongs. Taken together, the model provides guidelines for an indirect test for the presence of fixed time costs of work in order to analyze how market work may impose costs on (older) workers.

\section{Testing for the Presence of Fixed Time Costs of Market Work}

\section{A. Basic Results}

Ideally we would test for the impact of fixed costs by finding some kind of instrument that might help to identify the determinants of working in the market only a few hours versus not working. No such instrument is available in the ATUS; nor would one even appear to be imaginable were more data available. While instruments that might determine selectivity into market work have been used with some success (e.g., the now-classic use of the presence of young children by Heckman, 1976), finding an instrument that might convincingly determine selection into only a small amount of market work seems a daunting task.

Given this difficulty, I rely instead on examining how a person's allocation of non-market time changes when $\mathrm{s} /$ he crosses the threshold into market work. There are unobserved differences between those who engage in market work and those who do not; but if we still observe an apparent impact of fixed time costs as we restrict the sample to non-workers and those with successively fewer hours of market work, we may be somewhat more confident that we are measuring what the theory indicates. I thus estimate regressions relating minutes spent in secondary activities, tertiary activities and leisure to minutes spent in market work and an indicator WORK for whether or not any such minutes are spent. In these three equations the estimated coefficients on the former must, except for tiny differences due to the

\footnotetext{
${ }^{6}$ Fixed money costs of work create a "hole" in the distribution of hours of market work-it is not worthwhile to supply very few hours to the market. So do fixed time costs. The former, however, create a larger hole for those whose market wage rate is lower. The latter create a bigger gap in the distribution for workers whose value of time is greater.
} 
few minutes unaccounted for or unclassifiable in some diaries, sum to -1 . The estimated coefficients on the indicator for positive market work must (again with the minor exception) sum to 0 . If the fixed time costs of market work on time allocation outside the market create neutral effects, each of these latter three coefficients will equal zero. Thus a test for neutrality of market work (essentially a test for whether we can treat all non-market activities as separable from market work) is a test of the null hypothesis on these coefficients differing from each other.

In order to have a sufficient number of people who are working in the market and others who are not, I restrict the sample to people under age 60 . In addition to the measure of market work time and the indicator for market work I also include in the equations describing the allocation of non-market time a quadratic in age and indicators for whether the respondent is African-American or Hispanic and for the presence of children in various age categories (ages $0-2,3-5,6-13,14-17)$. In equations describing all individuals indicators for gender and marital status are included, while those equations, and the equations describing married people, also include a measure of spouse's hours of market work (CPS-style retrospective data on usual weekly hours). All the equations are weighted so that the estimates reflect behavior on a representative day of the week.

Table 3 presents the estimates of the three equations for the entire sample and then separately by marital status and gender. ${ }^{7}$ The first column in each panel lists the estimated effects of moving from no market work to an infinitesimal amount of work, while the second column shows the effect of adding one additional minute of market work. The results are striking: Among all these adults the impact of beginning market work is not neutral across secondary activities, tertiary activities and leisure. The estimates suggest a substantial negative effect on leisure activities and smaller positive effects on secondary and tertiary activities. A test of the equality of the three estimated parameters demonstrates that they are jointly significantly different from each other (and thus ipso facto jointly significantly different from zero).

\footnotetext{
${ }^{7}$ In order to examine the impact of differences in family income on the non-neutrality of fixed time costs I restrict the samples to those ATUS respondents for whom a measure of family income is available.
} 
Disaggregating the sample by marital status and gender changes the results somewhat, but they still suggest the same basic point. Among all four marital/gender categories beginning market work generates a shift of non-market time away from leisure and toward secondary activities. Among married men and single women both, the two groups for whom the effects are jointly significantly different from one another, there is also a shift away from tertiary activities. Moreover, the negative impacts on time spent in leisure activities are not greatly different from each other across the groups: The 24-minute daily decrease in leisure that I estimated results from beginning market work in the entire sample characterizes these subgroups fairly well. ${ }^{8}$

\section{B. Extensions and Tests for Robustness}

In Part A I restricted the sample to those under age 60 to allow large samples of workers and nonworkers. As a first check on the validity of the estimates, I redefine the sample to include all respondents 55 and over. The crucial results do not change greatly with this redefinition. While the coefficient on WORK in the equation for secondary activities is no longer statistically significant, the estimated effect on tertiary activities remains positive and significant, while that on leisure is negative and significant. Also, one rejects the hypothesis that the estimated impacts of WORK on the three categories of activity are zero.

Having demonstrated that the evidence is consistent with non-neutral fixed time costs of market work, we can test whether the change in behavior imposed by these costs can be overcome by purchasing market substitutes. The specifications in Table 3 are thus expanded to include a measure of household income and its interaction with the indicator for market work. Desiring to maintain parsimony in these interactions, and because the data on household income are categorical, I form the single indicator variable, income above $\$ 50,000$ per annum, and use only it.

The results of re-estimating the equations describing non-market allocations of time are shown for all married people, and for married men and women separately, in Table 4. The interaction terms in each case are of opposite sign from the main effect terms on WORK and are jointly significantly different

\footnotetext{
${ }^{8}$ Freeman and Schettkat (2005) compare older U.S. and German time-budget data and argue that longer U.S. hours of market work are offset by reductions in their home production. This may be true in the aggregate; but the results here make it absolutely clear that market and home production are complements at the margin of work at the individual level, with both substitutes for leisure.
} 
from zero in all three samples. A higher income moderates the non-neutrality of the fixed time costs of market work, allowing the individual to avoid giving up leisure and adding secondary or tertiary activities when he/she enters the labor market. Indeed, the results suggest that having a household income above the $\$ 50,000$ threshold (being in the upper $3 / 5$ of the distribution of household incomes) suffices to overcome completely the non-neutrality of the fixed time cost of market work. The results for married women, the majority of whose household incomes stems from their husband's earnings and from unearned income, are especially convincing of the impact of fixed time costs and of the role of higher income in enabling the household to offset those costs. ${ }^{9}$

We can use the estimates in Tables 3 and 4 to measure the impact of market work on the allocation of time outside the market. For the entire sample used in those estimates, the average worker cuts his/her secondary time by 36 percent, tertiary time by 7 percent and leisure by 42 percent compared to an otherwise identical non-worker. Among workers in households with incomes above $\$ 50,000$, however, the corresponding decreases are 54 percent, 8 percent and 36 percent. Higher incomes enable families to purchase market substitutes for their secondary time and mitigate the reduction in leisure.

As noted above, one might well be concerned that the average worker differs unobservably from non-workers, and that, rather than demonstrating the non-neutrality of the fixed time cost of market work, all I have shown is that non-workers in the sample have different household productivity than workers. I cannot completely refute that possibility. Some insight into the validity of this counter-argument can be obtained by restricting the sample to people who may be more similar, namely those who work zero or relatively few hours in the market. The upper panel of Table 5 restricts the sample respectively to individuals working fewer than 4 hours in a day, or fewer than 2 hours in a day, in the market. In both cases we observe, as in Table 3, that there is a significant non-neutrality of beginning market work. As in the results based on the unrestricted sample, and excluding the roughly 5000 people who are observed working 4 hours or more, we again find that beginning market work generates a roughly half-hour reduction in leisure activities. Unlike in the entire sample, however, it also generates a reduction in

\footnotetext{
${ }^{9}$ If we restrict the sample to married women observed on weekdays and working fewer than 240 minutes on those days, which cuts the sample by 75 percent, we still observe the same general results - a moderation of the apparent non-neutrality of fixed time costs as income increases.
} 
tertiary activities, and leads to a large increase in secondary activities. The results are nearly identical if we restrict the sample further to exclude the over 500 workers putting in between 2 and 4 hours on the diary-day.

The results disaggregated by gender and marital status, shown in the bottom two panels of Table 5, look remarkably like those presented for the aggregates of short-hours workers and non-workers. The impacts of starting work are statistically unequal for married men and single women, but also now among married women too. As observed throughout, leisure activities are diminished, while secondary activities increase. The results suggest that the findings for the entire sample are not an artifact of including workers who are far beyond the margin of deciding whether to enter the labor force. ${ }^{10}$

Yet another possibility is that those with strong preferences for leisure have inherently different set-up costs for different non-market activities from those whose tastes for leisure are weaker. We can take advantage of the ATUS over-sampling on weekends and its CPS information on weekly hours of market work to examine how the allocation of time of those did not work on a weekend day is affected by their total time devoted to the market. To do so I use the CPS weekly hours measure along with an indicator of positive weekly hours, substitute these two variables for the two variables that form the focus of Tables 3-5 and re-estimate the equations over weekend respondents who reported no market work on the diary day.

Table 6 presents the results. One should first note that each triad of coefficients should nearly (because of the small miscellaneous category) sum to zero, since there is no market work on the diary day. The first thing to note is that the vector of coefficients on the indicator of positive market work during the week is not significantly different from zero. There appear to be only small differences in setup costs between non-workers and others on days when no market work is performed. Additional hours of work during the week are not neutral with respect to the allocation of time on a non-working weekend

\footnotetext{
${ }^{10}$ Nor are they due to the inclusion of individuals who may usually work longer hours but who are observed on weekends. If the sample in the top panel of Table 3 is restricted to individuals observed on weekdays, the estimated impacts of beginning market work on the three aggregates of activities are 1.24, 25.72 and -26.15 minutes respectively, again significantly different from each other and from 0 . When the same restriction is applied to the sample in the left half of the upper panel of Table 4, the results are even more strikingly similar to those that include people whose diary-day covers a weekend day.
} 
day, however. ${ }^{11}$ They reduce leisure time on weekends and increase time devoted to secondary activities among those who do no market work on weekends. While not due to fixed costs, this may be one more reason for retirement - the first thing workers do with their "free time" on weekends is catch up on the secondary activities that the rigidities of their market work prevented them from doing during the workweek.

The "story" behind the fixed costs argument is one of setting up to go to work. The examples we gave were mostly classifiable as tertiary activities. If one works at home, the fixed costs that tilt nonmarket time to tertiary activities might be reduced, so that among at-home workers we would observe smaller effects on tertiary activities at the extensive margin of beginning work. I re-specify each of the equations presented in the top panel of Table 3 to include an indicator for whether and how much market work a person does at home. At the extensive margin of work there are no differences in leisure time between at-home workers and those who work away from home. Working away from home generates an initial extra 17 minutes of time in tertiary activities; but among at-home workers there is no impact at this extensive margin. On the other hand the impact at the extensive margin on secondary activities is nearly zero for those who work away from home but is 25 minutes for those who work at home. That there are no significant differences at the intensive margin between away and at-home workers on time spent in any of the three categories suggests the validity of the fixed-cost argument.

The estimates in this Section do not prove the existence of non-neutral fixed time costs of market work. In several ways, however, particularly the consistent pattern of a shift from leisure activities to secondary activities when market work hours are few but positive and the apparent diminution of that shift as household incomes increase, they are consistent with this type of fixed cost. They suggest that market work imposes some additional constraints on those who choose it, constraints that increase the incentives for complete retirement rather than a gradual reduction in market hours as people become eligible for public and/or private pensions.

\footnotetext{
${ }^{11} \mathrm{~A}$ test of the equality of the three estimated parameters yields $\chi^{2}=14.52$.
} 


\section{Switching Activities and the Impact of Set-up Costs}

Just as additional hours of market work appear to generate changes in behavior, set-up costs to the non-market activities that people undertake, be they eating, napping, television viewing, or whatever, may also alter behavior. Walking from the family room, where one has been watching television, to the kitchen, where one prepares a snack, takes time that does not directly contribute to satisfaction. As Hamermesh (2005) shows, these costs generally reduce the variability of scheduling across days, leading to routine in the timing of activities. A simple model would recognize that in each time period the consumer must choose whether to continue an activity or to switch to a new one, and that the choice may be affected by the amount of market work undertaken.

Assume that an individual's marginal cost of switching activities is constant, independent of the nature of the switch or the number of switches made. Then the consumer's daily decision problem is to maximize utility, defined over the T daily time periods as:

$$
\mathrm{U}=\mathrm{U}\left(\mathrm{s}_{1} \mathrm{~A}_{1}(1), \ldots, \mathrm{s}_{\mathrm{t}} \mathrm{A}_{\mathrm{t}}(1), \ldots, \mathrm{s}_{\mathrm{T}} \mathrm{A}_{\mathrm{T}}(1)\right)+\mathrm{V}\left(\mathrm{S}_{2}+\ldots+\mathrm{S}_{\mathrm{T}}\right)
$$

where $S_{t}$ is an indicator equaling 1 if the consumer switches activities between periods $t-1$ and $t$; each $\mathrm{A}_{\mathrm{t}}(\mathrm{t})$ indicates the activity undertaken during time slot $\mathrm{t}$, and $\mathrm{s}_{\mathrm{t}}=\mathrm{s}(\mathrm{w})<1, \mathrm{~s}^{\prime}<0$, if the activity at time $\mathrm{t}$ differs from that at time $\mathrm{t}-1,1$ if not. I make the usual assumptions about $\mathrm{U}$, and assume that $\mathrm{V}^{\prime}>0, \mathrm{~V}^{\prime}$ " $<0$. $\mathrm{S}_{\mathrm{t}}$ is the cost of switching activities from one to the other - the cost of temporal variety over the day. Such variety is costly because of the time lost to switching; it is also beneficial to the consumer because of the boredom of doing the same thing for long periods of time (reflected in V). I model the cost of switching as an increasing function of the value of time, proxied here by the wage rate.

The consumer maximizes this function, choosing which activity to consume/produce in each time slot $\mathrm{t}$, subject to the goods budget constraint:

$$
\underset{\mathrm{t}}{\Sigma \mathrm{p}_{\mathrm{a} 1} \Sigma \mathrm{X}_{\mathrm{a} 1}}=\underset{\mathrm{W}}{\mathrm{W}} \Sigma \mathrm{T}_{\mathrm{M}, \mathrm{t}}+\mathrm{I}
$$

where I is the person's unearned income, and the $\mathrm{X}$ are the market goods that are complementary with a particular activity A (assumed, following Becker (1965), to be combined with time using a Leontief-type technology). The maximization of (6) yields a sequence of equilibrium outcomes $\mathrm{S}_{\mathrm{t}}$ describing whether the person switches activities at time t. The retired person is assumed to have an opportunity cost of 0 (or 
at least lower than that of an otherwise identical non-worker). S/he thus has a higher $\mathrm{s}(\mathrm{w})$, reducing the cost of switching activities. Also, increases in I (unearned or from the older person's spouse) increase the demand for switching because of the assumption that temporal variety is superior (supported by evidence in Hamermesh, 2005). We should thus expect to observe that retirees will switch activities more than otherwise identical workers, and that individuals with higher unearned incomes will also enjoy more variety in their scheduling over the day.

The relaxation of scheduling constraints (because a person no longer works in the market) is equivalent in the frequency domain to an income effect. We should expect that non-workers undertake more different activities during the day than will otherwise identical working Americans. Initially using all observations in the ATUS I thus estimate:

$$
\mathrm{S}=\mathrm{F}\left(\text { WORK; } \mathrm{T}_{\mathrm{M}} ; \mathrm{Z}\right)
$$

where $\mathrm{S}=\Sigma \mathrm{S}_{\mathrm{t}}$. I will also expand (7) to account for the possibility that the same activities will be undertaken more frequently during the day by adding NACTS, the number of different activities that the respondent undertakes. In evaluating the results of estimating (7) I concentrate particularly on the impact of age (included) in the vector $\mathrm{Z}$ and the variables $\mathrm{T}_{\mathrm{M}}$ and WORK.

If we find this hypothesized difference between otherwise identical workers and non-workers, we may infer that differences in the relative well-being of older people and the advantage of retirement are greater than would be indicated merely by looking at monetary outcomes. Finding differences between older and younger people who work the same amount of time in the market would be particularly interesting, as it would indicate the role of taste differences (or other non-quantifiable changes with age). Even without solving the causation problem, the findings may allow us to link the results to inferences about the value of restructuring market work to allow for more flexible timing.

As a first step in the analysis in this sub-section I simply inquire into how the number of activity switches changes with age and how it varies with labor-force participation. The first row of Table 7 lists the mean number of switches by age group in the ATUS. These descriptive statistics suggest that younger people (under age 55) jump among activities more frequently than do older people. However, among the latter there appear to be no significant differences by age, except that those $75+$ report staying 
with a particular activity longer than those ages 55-74. Whether these differences by age reflect the underlying effects of aging (on the ability or willingness to undertake more activities, or on memory); differences in family circumstances (e.g., we know, Gronau and Hamermesh, 2001, that the presence of young children leads their parents to undertake more different activities in the day), or to differences in incomes and the price of time, is unclear.

We can adjust these raw differences for a number of characteristics, however, including educational attainment, spouse's work hours, racial/ethnic/gender mix, marital status and the presence of children of various ages, and, most important, for the distribution of time spent in the four major activity types. The results are shown in the second row of Table 7. It is clear that most of the differences between younger people and most groups of older people shown in the top row are illusory. Once we adjust for these covariates, only those respondents ages 75 or over switch activities less frequently than others. There are no significant differences by age in switching between activities under age $75 .{ }^{12}$

The analysis of switches may mask underlying differences in the demand not just for temporal variety, but also for variety in the kinds of activities enjoyed (see Gronau and Hamermesh, 2001). To the extent that the underlying demand is correlated with age, the estimated age differences in the second row may be biased. To account for this possibility, in the third row of Table 7 I present the means by age of the number of different activities (6-digit activities in the ATUS) undertaken on the diary-day. The numbers are unsurprisingly far below those in the first row: One may eat three meals per day, watch television during several discrete time periods, etc. The means show that there is a nearly steady decline in the amount of variety generated as one ages beyond the mid-50s. When, however, we adjust for demographic differences and differences in the amounts of time allocated to market work, secondary activities, and tertiary activities (and implicitly leisure), we find that most of the differences are illusory. Americans ages 70-74 undertake marginally significantly fewer distinct activities than others, while those 75 and over do engage in fewer different things over the day.

To examine these arguments directly I estimate a direct analogue of equation (7). The dependent variable is the number of switches made during the day (one less than the number of distinct time slots in

\footnotetext{
${ }^{12}$ Including an indicator of family income above $\$ 50,000$ does not qualitatively alter this conclusion.
} 
which the respondent coded an activity). The first set of estimates, shown in Column (1) of Table 8, shows a few more of the coefficient estimates from the regression for which the age effects were presented in the second row of Table 7. Not surprisingly, the parameter estimates describing the effects of additional time spent in activities are highly significant statistically: Some activities, albeit defined finely, are typically of long duration (e.g., market work), while others (e.g., preparing breakfast) typically take little time. The second column includes the crucial variable WORK. Quite contrary to my prediction, its effect is positive and huge (implying over a 30 percent difference in the number of activity switches between a person who works a little bit in the market and another who supplies no time to market work. Given the mean time devoted to market work in this sample (221 minutes per representative day), the results imply that the average worker switches activities only 85 percent as frequently as an otherwise identical non-worker.

The likely reason for this surprising result is that the equation fails to hold constant for the amount of variety that people generate. Different activities that workers undertake (market work and fewer secondary activities and leisure) are inherently more likely to be undertaken less frequently during the day. Thus to measure the potential influence of the fixed costs of working in the market on switching among activities we need to adjust for the amount of variety in the activities undertaken. The estimates in Column (3) of Table 8 do this by including a cubic in NACTS. ${ }^{13}$ They show that, once we account for the amount of variety generated, working in the market does indeed reduce the number of switches. The fact of working per se reduces a person's flexibility in switching among activities, conditional on his/her demographic characteristics and choices about the kinds and number of different activities to undertake. As the estimates in Columns (4) and (5) show, the effects are larger on weekends, presumably because such work is less common.

\section{Section VI. The Timing of Activities}

Yet another potential non-neutral effect of additional market work and the fixed cost of beginning market work on time use at home is on the temporal pattern of daily activities. That is, conditional on the

\footnotetext{
${ }^{13}$ The estimates in this Table include all respondents to the ATUS. Their implications vary only slightly if we restrict the sample to those under age 60. Also, the estimates in Columns (3)-(5) change very little if only a linear term in NACTS is included.
} 
amount of an activity (secondary, tertiary or leisure) undertaken over the day, are the times at which those non-market activities are undertaken affected by the amount of market work and by the fixed cost of beginning market work? In other words, is there an instantaneous non-neutrality of market work on household activities analogous to the integrative impacts I demonstrated in Section IV?

To examine this possibility I estimate equations:

$$
\mathrm{P}_{\mathrm{At}}=\mathrm{H}\left(\mathrm{T}_{\mathrm{A}} ; \text { WORK; } \mathrm{T}_{\mathrm{M}} ; \mathrm{Z}\right), \mathrm{A}=\mathrm{S}, \mathrm{T}, \mathrm{L} ; \mathrm{t}=1, \ldots, 96 \text {, }
$$

where $\mathrm{P}_{\mathrm{At}}$ is an indicator equaling one if activity A was performed during quarter-hour $\mathrm{t}$. These equations are analogous to those estimated in Sections IV and V, except that here I am holding constant the total amount of time spent in activity A to concentrate on how its diurnal distribution is affected by market work. The sum of the coefficients on the $T_{A}$ across the $t$ should equal zero, since total time spent in $A$ over the day is $15 \Sigma \mathrm{P}_{\mathrm{At}}$. Thus conditional on $\mathrm{T}_{\mathrm{A}}$ the coefficient estimates of $\mathrm{T}_{\mathrm{M}}$ show whether an additional minute of market work alters the temporal pattern of the activity A. Similarly, again conditional on $\mathrm{T}_{\mathrm{A}}$, the estimated coefficients on WORK show whether the discrete choice to begin market work alters the temporal pattern of the activity A and thus provide a test of the impact of the fixed costs of market work on the timing of household activities.

The raw ATUS data are presented in sequence, with each activity having a particular starting time (coded to the minute). For purposes of analysis, as is implicit in (8) I combine the data into periods of 96 quarter-hours, examining what each respondent was doing during each quarter-hour beginning at 4AM and ending at 3:59AM the next day. ${ }^{14}$ Before proceeding to the estimation, and analogous to the presentation in Section IVA, I first provide information on the temporal patterns of activities for people under age 55 and 55 or over, then examine how these patterns differ among groups of older Americans. Clearly, there is a massive amount of information here; the only useful approach is to present it graphically, which I do throughout the rest of this Section.

\footnotetext{
${ }^{14}$ Where more than one activity was in progress during a quarter-hour, I included the one which comprised the majority (or plurality) of the 15 minutes. In the very few instances where more than two activities were in progress for the same length of time I coded the first of them as representing the quarter-hour.
} 
Figures 1a-1d show the daily patterns of market work, secondary activities, tertiary activities and leisure for people under 55 and those $55+{ }^{15}$ (The graphs present the mean fractions of people in the group engaged in the activity at the particular quarter-hours.) Most of the differences between the two age groups are the unsurprising result of the higher incidence of market work among the younger sub-sample. The diurnal patterns of market work are identical between the two age groups, with the downward shift among the older group at each point being nearly directly proportional to their lower market participation. ${ }^{16}$

The time patterns of tertiary activities differ little across these two groups; and even the timing of leisure differs little once we account for differences in market work, a mainly daytime activity. The main interesting difference is in the temporal pattern of secondary activities. Younger people perform their secondary activities (household production) disproportionately during the late afternoon and evening when they are less likely to be working; older people, perhaps to avoid congestion costs at times when more younger people are at their workplaces, perform these activities disproportionately during the prime daytime hours.

Strikingly, the difference in the pattern of the timing of secondary activities by age exists even among those whose time diary showed no market work and who responded to the CPS question about usual hours of work by saying theirs were zero, as Figure 2a shows. Even non-working younger people engage in household production disproportionately in the late afternoon and early evening, at times when older Americans disproportionately engage in leisure activities, as shown in Figure 2c. Since the main difference in the kinds of leisure undertaken across age groups is that older people watch more television, the differences reflect the greater attractions of prime-time television to older audiences. Differences in the timing of tertiary activities (Figure 2b) by major age group are slight—-those under or over 55 sleep, eat, etc. at roughly the same times. The only significant differences are that older Americans are more likely to engage in tertiary activities between $11 \mathrm{PM}$ and $4 \mathrm{AM}$, and less likely to do so from $8 \mathrm{AM}$ to

\footnotetext{
${ }^{15}$ All the data and coefficients presented in the Figures in this Section are based on statistics that have been weighted to provide information on a representative day of the week.

${ }^{16}$ This finding is consistent with the evidence in Hamermesh (1999) on self-reported work patterns by age in the CPS.
} 
11AM. Since sleep accounts for most tertiary time use, these differences reflect older Americans going to bed and waking up earlier than younger people.

Figures 3a-3d depict the coefficients and confidence intervals around them on indicators of age from regressions describing each of the four main types of activities for samples of individuals age 60 and over. In each equation the total time spent in the activity over the day is held constant, so that the coefficients illustrate temporal variety adjusted for the intensity of the activity. The horizontal line at zero indicates the effect for the base group, persons ages 60-64. Figure 3 a shows that people older than this base group are more likely to do what market work they accomplish during afternoons and less likely to do it during mornings. The differences are rarely significant, however. The main differences (which occur chiefly between those $75+$ and those 60-64) are in the timing of secondary activities and leisure. The oldest group engages in relatively few secondary activities during prime daytime hours compared to people a few years younger. Obversely, they engage in leisure activities disproportionately during those times compared to people 60-64 and even to those ages 65-69. Quite different from the results in Section IV for the total amounts of time devoted to different activities, the major differences in the diurnal distribution of time among older Americans are between their use of time in secondary activities and leisure; there are few significant differences in the timing of tertiary activities across the population ages $60+$.

In Figure 4a I present the temporal patterns of the coefficients on the variable WORK from the three sets of equations (8). Each point represents a regression coefficient at a particular quarter-hour of the day, and around each point is a 95-percent confidence interval. The very fact of being in the labor market, even for only a few hours in a day, causes significant displacement in the timing of activities conditional on the total amounts undertaken. Particularly interesting are the displacement of leisure away from prime working hours and the displacement of secondary activities to late afternoon and early evening. In addition to the increase in the amount of secondary activities and reducing leisure shown in Section IV, the presence of labor-market activity also causes temporal displacements in the performance of these other activities. 
Figure $4 \mathrm{~b}$ presents the same kind of information, but for the coefficients on $\mathrm{T}_{\mathrm{M}}$ from the estimates of equations (8). It shows that additional time devoted to market work, conditional on being in the labor market, has especially large effects on the timing of tertiary activities. The marginal effect of another minute of market work is biggest on sleeping, eating, etc. during normal waking hours. The effects on leisure are also large and significant, and indicate that additional minutes of market work shift leisure away from prime daytime working hours. The impacts of an additional minute of work time on the timing of secondary activities are smaller, with the biggest shift being toward conducting secondary activities during evening hours.

For each of the three non-market activity aggregates Figures 5a-5c show the coefficients at each quarter-hour on WORK and an interaction of WORK with the indicator of family income above $\$ 50,000$ per year. The underlying regressions and samples are identical to those partly described in Figures $4 \mathrm{a}$ and $4 \mathrm{~b}$, except for the addition of this interaction and a main-effect term in the indicator. The question is whether the impact of labor-market participation differs between otherwise identical workers who are in higher- or lower-income households. A test of that possibility is whether the confidence intervals around the dotted lines in Figures 5 include the zero line. While they do in many cases, in many others they do not. More often than not, however, the coefficients on the interaction term between higher income and WORK are of opposite signs, suggesting that additional family income mitigates the disturbance to the timing of household activities generated by labor-force participation. The correlation of the coefficients on WORK and its interaction with family income in the equations for secondary activities is +0.19 (48 of 96 opposite signs); the correlation of the two coefficients in the equation for tertiary activities is -0.61 (63 opposite signs); that for leisure is -0.38 (53 opposite signs). The correlation and number of oppositesigned coefficients in the equations describing tertiary activities are significantly different from what is expected under the null hypothesis of randomness, as is the correlation coefficient for the estimates for leisure. These results suggest that people in higher-income households are able to use their income to overcome some of the set-up costs that market work imposes on the timing of non-market activities.

The final set of figures, $6 a$ and $6 \mathrm{~b}$, is analogous to Figures $4 \mathrm{a}$ and $4 \mathrm{~b}$, except the sample is restricted to individuals whose diaries describe weekend days when they did no market work, but who 
report positive hours of market work for the week. Here, analogous to the integrative analysis in Section IV, the purpose is to examine whether it is market work per se that alters schedules, or whether workers' home schedules differ from others' schedules for reasons not having to do with time spent in the market on the particular day. Comparing these figures to Figures $4 \mathrm{a}$ and $4 \mathrm{~b}$, there are only slight effects of having worked in the market on weekdays on the timing of a given amount of other activities over the weekend. What matters most for the determination of timing is work on the particular day. As in Section $\mathrm{IV}$, there is only weak evidence that those who work only on weekdays behave on the weekends any differently from otherwise identical people who do not work in the market at all.

\section{Conclusions}

Suffice it to note that the mere fact of participation in the labor market, even for a short while, alters both the distribution of non-market activities and their timing. Neither the discrete move to participation nor marginal increases in hours of work are neutral with respect to the kinds of activities undertaken outside the market, even when we confine the analysis to the three broad aggregates secondary activities, tertiary activities and leisure. Working in the market increases the amount of secondary activities performed relative to the amount of leisure consumed; and the diurnal distributions of these three major aggregates are altered on working days when a person enters the labor market and when/s/he increases hours of market work. 


\section{REFERENCES}

Gary Becker, “A Theory of the Allocation of Time,” Economic Journal, 75 (September 1965): 493-517.

Jeff Biddle and Daniel Hamermesh, "Sleep and the Allocation of Time," Journal of Political Economy, 98 (October 1990): 922-43.

John Cogan, “Fixed Costs and Labor Supply,” Econometrica, 49 (July 1981): 945-963.

Richard Freeman and Ronald Schettkat, "Marketization of Household Production and the EU-US Gap in Work," Economic Policy, 41 (Jan. 2005): 5-39.

Anne Gauthier and Timothy Smeeding, "Time Use at Older Ages: Cross-National Differences," Research on Aging, 25 (May 2003): 247-274.

Reuben Gronau and Daniel Hamermesh, "The Demand for Variety: A Household Production Perspective,” NBER Working Paper No. 8509, October 2001.

Alan Gustman and Thomas Steinmeier, "Minimum Hours Constraints, Job Requirements, and Retirement," National Bureau of Economic Research, Working Paper No. 10876, November 2004.

Daniel Hamermesh, “The Timing of Work Time Over Time,” Economic Journal, 109 (1999): 37-66.

, "Timing, Togetherness and Time Windfalls," Journal of Population Economics, 15 (2002): 601-623.

, "Routine," European Economic Review, 49 (January 2005): 29-53.

, Harley Frazis and Jay Stewart, "Data Watch: The American Time Use Survey,” Journal of Economic Perspectives, 19 (Winter 2005): 221-232.

James Heckman, "The Common Structure of Statistical Models of Truncation, Sample Selection and Limited Dependent Variables and a Simple Estimator for Such Models," Annals of Economic and Social Measurement, 5 (Fall 1976): 475-92

Michael Horrigan and Diane Herz, "A Study in the Process of Planning, Designing and Executing a Survey Program: The BLS American Time-Use Survey," in Daniel Hamermesh and Gerard Pfann, eds., The Economics of Time Use. Amsterdam: North-Holland, 2005.

Robin Lumsdaine and Olivia Mitchell, "New Developments in the Economic Analysis of Retirement," in Orley Ashenfelter and David Card, eds., Handbook of Labor Economics, Vol 3C. Amsterdam: North-Holland, 1999.

Organization for Economic Cooperation and Development, Communiqué of Labour Ministers, 2003.

Margaret Reid, Economics of Household Production. New York: Wiley, 1934. 
Liana C. Sayer, Suzanne M. Bianchi and John P. Robinson, "Time Use Patterns of Older Americans," Report to NIA, University of Maryland, June 30, 2001.

Pitirim Sorokin and Clarence Berger, Time Budgets of Human Behavior. Cambridge: Harvard University Press, 1939.

Gordon Winston, The Timing of Economic Activities. New York: Cambridge University Press, 1982. 
Table 1. Mean Time Use by Age, ATUS 2003 (Minutes per Representative Day)*

\begin{tabular}{|c|c|c|c|c|c|c|}
\hline & & & & Age & & \\
\hline Activity & $<55$ & $55-59$ & $60-64$ & $65-69$ & $70-74$ & $75+$ \\
\hline Market work: & $\begin{array}{r}263.08 \\
(2.38)\end{array}$ & $\begin{array}{c}261.31 \\
(7.13)\end{array}$ & $\begin{array}{c}164.11 \\
(7.20)\end{array}$ & $\begin{array}{l}78.95 \\
(5.70)\end{array}$ & $\begin{array}{l}55.58 \\
(5.58)\end{array}$ & $\begin{array}{l}14.00 \\
(1.80)\end{array}$ \\
\hline Secondary: & & & & & & \\
\hline Household production & $\begin{array}{r}155.82 \\
(1.33)\end{array}$ & $\begin{array}{r}185.60 \\
(4.45)\end{array}$ & $\begin{array}{r}206.26 \\
(5.30)\end{array}$ & $\begin{array}{r}216.02 \\
(5.56)\end{array}$ & $\begin{array}{r}222.50 \\
(6.46)\end{array}$ & $\begin{array}{r}204.09 \\
(4.09)\end{array}$ \\
\hline Family care & $\begin{array}{l}78.64 \\
(1.04)\end{array}$ & $\begin{array}{l}41.45 \\
(2.56)\end{array}$ & $\begin{array}{l}44.93 \\
(2.86)\end{array}$ & $\begin{array}{l}45.14 \\
(3.17)\end{array}$ & $\begin{array}{l}40.63 \\
(3.40)\end{array}$ & $\begin{array}{l}33.15 \\
(2.30)\end{array}$ \\
\hline $\begin{array}{l}\text { Tertiary: } \\
\text { Sleep }\end{array}$ & $\begin{array}{r}507.06 \\
(1.11)\end{array}$ & $\begin{array}{c}494.51 \\
(3.16)\end{array}$ & $\begin{array}{r}510.31 \\
(3.42)\end{array}$ & $\begin{array}{r}518.67 \\
(3.58)\end{array}$ & $\begin{array}{r}530.04 \\
(4.03)\end{array}$ & $\begin{array}{r}537.18 \\
(3.16)\end{array}$ \\
\hline Personal care & $\begin{array}{l}45.93 \\
(0.44)\end{array}$ & $\begin{array}{l}49.42 \\
(1.49)\end{array}$ & $\begin{array}{l}51.24 \\
(2.19)\end{array}$ & $\begin{array}{l}52.55 \\
(2.90)\end{array}$ & $\begin{array}{l}46.28 \\
(2.20)\end{array}$ & $\begin{array}{l}50.99 \\
(2.01)\end{array}$ \\
\hline Eating and drinking & $\begin{array}{l}67.40 \\
(0.50)\end{array}$ & $\begin{array}{l}75.20 \\
(1.49)\end{array}$ & $\begin{array}{l}84.41 \\
(1.95)\end{array}$ & $\begin{array}{l}85.43 \\
(3.17)\end{array}$ & $\begin{array}{l}90.97 \\
(2.28)\end{array}$ & $\begin{array}{l}90.52 \\
(1.64)\end{array}$ \\
\hline Leisure: & $\begin{array}{r}309.72 \\
(1.88)\end{array}$ & $\begin{array}{r}317.93 \\
(5.36)\end{array}$ & $\begin{array}{c}364.18 \\
(6.23)\end{array}$ & $\begin{array}{r}424.03 \\
(6.94)\end{array}$ & $\begin{array}{r}435.06 \\
(7.44)\end{array}$ & $\begin{array}{r}485.11 \\
(5.21)\end{array}$ \\
\hline Other & $\begin{array}{l}12.34 \\
(0.40)\end{array}$ & $\begin{array}{l}14.58 \\
(1.24)\end{array}$ & $\begin{array}{l}14.55 \\
(1.81)\end{array}$ & $\begin{array}{l}19.20 \\
(1.60)\end{array}$ & $\begin{array}{l}18.94 \\
(2.06)\end{array}$ & $\begin{array}{l}24.95 \\
(1.99)\end{array}$ \\
\hline $\mathrm{N}=$ & 14450 & 1591 & 1201 & 1052 & 848 & 1578 \\
\hline
\end{tabular}

*Standard errors of the means in parentheses. The estimates in all tables are weighted to reflect equal numbers of observations on each of the seven days of the week. 
Table 2. Impact of Age and Other Demographics on Time Use, 4,679 Individuals 60+, ATUS 2003 (Minutes per Representative Day)*

$\begin{array}{lcccccccc} & 65-69 & 70-74 & 75+ & \text { Black } & \text { Hispanic } & \text { Male } & \text { Married } \\ \text { Activity } & & & & & & & \\ \text { Market work: } & -85.45 & -108.83 & -150.07 & -27.74 & 2.62 & 54.39 & -13.58 \\ & (7.26) & (7.75) & (6.76) & (8.22) & (10.37) & (5.32) & (5.42) \\ & & & & & & & \\ \text { Secondary: } & 11.16 & 16.78 & -3.09 & -57.33 & -13.43 & -80.40 & 27.96 \\ \text { Household production } & (7.25) & (7.78) & (6.75) & (8.20) & (10.36) & (5.31) & (5.41) \\ & & & & & & & \\ & & & & & & & & \\ \text { Family care } & (4.10) & (4.38) & (3.82) & (4.65) & (5.87) & (3.01) & (3.57) \\ & & & & & & & \\ \text { Tertiary: } & 8.28 & 21.08 & 30.09 & 31.33 & 39.09 & 3.65 & 3.32 \\ \text { Sleep } & (5.09) & (5.43) & (4.74) & (5.76) & (7.27) & (3.73) & (3.80) \\ & 1.30 & -5.49 & -2.56 & 19.20 & 4.39 & -19.03 & -5.39 \\ \text { Personal care } & (3.33) & (3.56) & (3.10) & (3.77) & (4.77) & (2.44) & (2.49) \\ & 1.21 & 6.90 & 7.81 & -34.28 & -14.84 & 10.31 & 8.45 \\ \text { Eating and drinking } & (2.47) & (2.93) & (2.56) & (3.11) & (3.93) & (2.01) & (2.05) \\ & & & & & & & \\ \text { Leisure: } & 58.60 & 69.34 & 117.94 & 71.43 & 3.88 & 40.39 & -30.98 \\ & (8.99) & (9.61) & (8.38) & (10.18) & (12.86) & (6.59) & (6.71)\end{array}$

*Standard errors in parentheses here and in Tables 3-6. The excluded age category is 60-64 years old. 
Table 3. Impacts of Market Work on Daily Minutes of Other Activities, ATUS 2003, Individuals $<60$ (Minutes per Representative Day)

\begin{tabular}{lccc} 
& \multicolumn{3}{c}{ All Individuals } \\
& WORK & Minutes of Work & $\mathrm{R}^{2}$ \\
Secondary & 13.53 & -0.370 & 0.404 \\
Activities & $(5.06)$ & $(0.009)$ & \\
& 10.35 & -0.216 & 0.172 \\
Tertiary & $(4.16)$ & $(0.007)$ & \\
Activities & -24.49 & -0.393 & 0.439 \\
& $(5.26)$ & $(0.009)$ & \\
Leisure & 22.02 & 14398 & \\
& \multicolumn{3}{c}{ Married Men }
\end{tabular}

WORK Minutes of Work $\mathrm{R}^{2}$

\begin{tabular}{|c|c|c|c|c|c|c|c|}
\hline $\begin{array}{l}\text { Secondary } \\
\text { Activities }\end{array}$ & $\begin{array}{l}4.65 \\
(9.45)\end{array}$ & & $\begin{array}{l}-0.362 \\
(0.014)\end{array}$ & 0.347 & $\begin{array}{l}21.04 \\
(9.90)\end{array}$ & $\begin{array}{l}-0.501 \\
(0.019)\end{array}$ & 0.422 \\
\hline $\begin{array}{l}\text { Tertiary } \\
\text { Activities }\end{array}$ & $\begin{array}{l}26.73 \\
(7.11)\end{array}$ & & $\begin{array}{l}-0.237 \\
(0.011)\end{array}$ & 0.235 & $\begin{array}{l}-1.48 \\
(7.18)\end{array}$ & $\begin{array}{l}-0.176 \\
(0.134)\end{array}$ & 0.144 \\
\hline Leisure & $\begin{array}{r}-33.94 \\
(9.49)\end{array}$ & & $\begin{array}{l}-0.376 \\
(0.014)\end{array}$ & 0.428 & $\begin{array}{r}-13.97 \\
(9.05)\end{array}$ & $\begin{array}{l}-0.312 \\
(0.018)\end{array}$ & 0.264 \\
\hline$\chi^{2}(2) ; \mathrm{N}=$ & 20.22 & 3626 & & & 4.07 & 4225 & \\
\hline
\end{tabular}

Single Men

WORK Minutes of Work $\mathrm{R}^{2} \quad$ WORK $\quad$ Minutes of Work $\quad \mathrm{R}^{2}$

\begin{tabular}{|c|c|c|c|c|c|c|c|}
\hline $\begin{array}{l}\text { Secondary } \\
\text { Activities }\end{array}$ & $\begin{array}{l}17.05 \\
(10.83)\end{array}$ & & $\begin{array}{l}-0.238 \\
(0.019)\end{array}$ & 0.175 & $\begin{array}{r}33.24 \\
(10.44)\end{array}$ & $\begin{array}{l}-0.364 \\
(0.020)\end{array}$ & 0.293 \\
\hline $\begin{array}{l}\text { Tertiary } \\
\text { Activities }\end{array}$ & $\begin{array}{c}-2.77 \\
(10.99)\end{array}$ & & $\begin{array}{l}-0.223 \\
(0.019)\end{array}$ & 0.158 & $\begin{array}{l}12.95 \\
(9.23)\end{array}$ & $\begin{array}{l}-0.234 \\
(0.017)\end{array}$ & 0.140 \\
\hline Leisure & $\begin{array}{l}-20.90 \\
(13.41)\end{array}$ & & $\begin{array}{l}-0.511 \\
(0.023)\end{array}$ & 0.481 & $\begin{array}{l}-46.44 \\
(11.36)\end{array}$ & $\begin{array}{l}-0.385 \\
(0.021)\end{array}$ & 0.437 \\
\hline$\chi^{2}(2) ; \mathrm{N}=$ & 3.54 & 2837 & & & 17.58 & & \\
\hline
\end{tabular}

*All the estimating equations here and in Tables 4-6 include a quadratic in age, and indicators for African-American and Hispanic and the presence of children in various age categories. Those for all workers also include indicators for marital status and gender; they and the equations for married individuals in Tables 4 and 5 also include a measure of spouse's hours of market work. 
Table 4. Impacts of Market Work on Daily Minutes of Other Activities, ATUS 2003, Individuals $<60$, with Income Interactions (Minutes per Representative Day)

\begin{tabular}{lcccc}
\multicolumn{5}{c}{ All Individuals } \\
& WORK & WORK x Income $>50 \mathrm{~K}$ & Minutes of Work & $\mathrm{R}^{2}$ \\
Secondary & 13.85 & -23.46 & -0.410 & 0.451 \\
Activities & $(8.28)$ & $(7.74)$ & $(0.012)$ & \\
Tertiary & 19.39 & -7.48 & -0.211 & 0.194 \\
Activities & $64087)$ & $(5.68)$ & $(0.009)$ & \\
Leisure & -31.54 & 30.70 & -0.360 & 0.348 \\
& $(7.85)$ & $(7.39)$ & $(0.011)$ & \\
$\chi^{2}(3) ; \mathrm{N}=$ & & 21.45 & 7851 & \\
\end{tabular}

\section{Married Men}

WORK WORK $x$ Income $>50 \mathrm{~K} \quad$ Minutes of Work $\quad \mathrm{R}^{2}$

\begin{tabular}{|c|c|c|c|c|}
\hline $\begin{array}{l}\text { Secondary } \\
\text { Activities }\end{array}$ & $\begin{array}{c}28.05 \\
(11.77)\end{array}$ & $\begin{array}{l}-39.05 \\
(11.53)\end{array}$ & $\begin{array}{c}-0.363 \\
(13.06)\end{array}$ & 0.352 \\
\hline $\begin{array}{l}\text { Tertiary } \\
\text { Activities }\end{array}$ & $\begin{array}{l}29.53 \\
(8.89)\end{array}$ & $\begin{array}{l}-4.33 \\
(8.70)\end{array}$ & $\begin{array}{l}-0.236 \\
(0.011)\end{array}$ & 0.236 \\
\hline Leisure & $\begin{array}{l}-55.03 \\
(11.83)\end{array}$ & $\begin{array}{c}35.04 \\
(11.59)\end{array}$ & $\begin{array}{r}-0.375 \\
(10.44)\end{array}$ & 0.431 \\
\hline \multirow[t]{3}{*}{$\chi^{2}(3) ; \mathrm{N}=$} & \multicolumn{4}{|c|}{3626} \\
\hline & \multicolumn{4}{|c|}{ Married Women } \\
\hline & WORK & WORK $x$ Income $>50 \mathrm{~K}$ & Minutes of Work & $\mathrm{R}^{2}$ \\
\hline $\begin{array}{l}\text { Secondary } \\
\text { Activities }\end{array}$ & $\begin{array}{l}35.45 \\
(12.05)\end{array}$ & $\begin{array}{l}-23.39 \\
(10.82)\end{array}$ & $\begin{array}{c}-0.501 \\
(10.83)\end{array}$ & 0.423 \\
\hline $\begin{array}{l}\text { Tertiary } \\
\text { Activities }\end{array}$ & $\begin{array}{c}1.53 \\
(8.75)\end{array}$ & $\begin{array}{l}-5.04 \\
(7.86)\end{array}$ & $\begin{array}{l}-0.176 \\
(0.014)\end{array}$ & 0.144 \\
\hline Leisure & $\begin{array}{c}-33.89 \\
(10.99)\end{array}$ & $\begin{array}{l}32.62 \\
(9.87)\end{array}$ & $\begin{array}{l}-0.310 \\
(0.0180\end{array}$ & 0.269 \\
\hline$\chi^{2}(3) ; \mathrm{N}=$ & & 11.85 & & \\
\hline
\end{tabular}


Table 5. Impacts of Market Work on Daily Minutes of Other Activities, ATUS 2003, Individuals $<60$ Working Short or Zero Hours (Minutes per Representative Day)

\begin{tabular}{|c|c|c|c|c|c|c|}
\hline & \multicolumn{3}{|c|}{$\begin{array}{c}\text { All Individuals with <4 Daily Hours } \\
\text { of Market Work }\end{array}$} & \multicolumn{3}{|c|}{ All Individuals with $<2$ Daily Hours } \\
\hline & WORK & Minutes of Work & $\mathrm{R}^{2}$ & WORK & Minutes of Work & $\mathrm{R}^{2}$ \\
\hline $\begin{array}{l}\text { Secondary } \\
\text { Activities }\end{array}$ & $\begin{array}{c}61.18 \\
(10.06)\end{array}$ & $\begin{array}{l}-0.697 \\
(0.078)\end{array}$ & 0.286 & $\begin{array}{r}59.15 \\
(13.06)\end{array}$ & $\begin{array}{l}-0.595 \\
(0.232)\end{array}$ & 0.283 \\
\hline $\begin{array}{l}\text { Tertiary } \\
\text { Activities }\end{array}$ & $\begin{array}{r}-23.35 \\
(7.85)\end{array}$ & $\begin{array}{l}-0.060 \\
(0.061)\end{array}$ & 0.020 & $\begin{array}{l}-17.56 \\
(10.67)\end{array}$ & $\begin{array}{l}-0.212 \\
(0.180)\end{array}$ & 0.018 \\
\hline Leisure & $\begin{array}{c}-35.74 \\
(10.44)\end{array}$ & $\begin{array}{l}-0.260 \\
(0.081)\end{array}$ & 0.233 & $\begin{array}{l}-37.04 \\
(14.24)\end{array}$ & $\begin{array}{l}-0.256 \\
(0.241)\end{array}$ & 0.230 \\
\hline$\chi^{2}(2) ; \mathrm{N}=$ & 37.43 & 9093 & & 17.94 & 8532 & \\
\hline
\end{tabular}

Men

WORK Minutes of Work $\mathrm{R}^{2}$
Women

WORK Minutes of Work $\quad \mathrm{R}^{2}$

$\begin{array}{lll}56.51 & -0.794 & 0.130 \\ (18.38) & (0.147) & \\ -13.66 & -0.144 & 0.037 \\ (12.62) & (0.101) & \end{array}$

$-35.85$

$-0.064$

$(0.134)$

0.084
$\chi^{2}(2) ; \mathrm{N}=$
$11.20 \quad 1867$
$8.83 \quad 3007$

\section{Single with <4 Daily Hours of Market Work}

\begin{tabular}{|c|c|c|c|c|c|c|}
\hline & WORK & $\begin{array}{l}\text { Men } \\
\text { Minutes of Work }\end{array}$ & $\mathrm{R}^{2}$ & WORK & $\begin{array}{l}\text { Women } \\
\text { Minutes of Work }\end{array}$ & $\mathrm{R}^{2}$ \\
\hline $\begin{array}{l}\text { Secondary } \\
\text { Activities }\end{array}$ & $\begin{array}{c}42.81 \\
(23.14)\end{array}$ & $\begin{array}{l}-0.410 \\
(0.173)\end{array}$ & 0.124 & $\begin{array}{r}84.57 \\
(20.51)\end{array}$ & $\begin{array}{l}-0.778 \\
(0.154)\end{array}$ & 0.215 \\
\hline $\begin{array}{l}\text { Tertiary } \\
\text { Activities }\end{array}$ & $\begin{array}{l}-38.26 \\
(22.38)\end{array}$ & $\begin{array}{l}-0.078 \\
(0.167)\end{array}$ & 0.015 & $\begin{array}{l}-26.01 \\
(17.23)\end{array}$ & $\begin{array}{c}0.001 \\
(0.129)\end{array}$ & 0.015 \\
\hline Leisure & $\begin{array}{l}-15.78 \\
(28.41)\end{array}$ & $\begin{array}{l}-0.460 \\
(0.212)\end{array}$ & 0.104 & $\begin{array}{l}-54.14 \\
(22.12)\end{array}$ & $\begin{array}{l}-0.249 \\
(0.166)\end{array}$ & 0.188 \\
\hline$\chi^{2}(2) ; \mathrm{N}=$ & 5.45 & 1781 & & 16.02 & 2438 & \\
\hline
\end{tabular}


Table 6. Impacts of Market Work on Daily Minutes of Other Activities on Weekends, ATUS 2003, Individuals $<60$ with No Weekend Work

$\begin{array}{lccc} & \text { WORK } & \begin{array}{c}\text { Weekly Work } \\ \text { Hours }\end{array} & \mathrm{R}^{2} \\ \text { Secondary } & -10.54 & 0.818 & 0.178 \\ \text { Activities } & (11.75) & (0.275) & \\ & & 0.268 & 0.028 \\ \text { Tertiary } & -1.61 & (0.210) & \\ \text { Activities } & (8.96) & -1.093 & 0.126 \\ \text { Leisure } & 13.85 & (0.290) & \\ & (12.40) & & \\ \chi^{2}(2) ; \mathrm{N}= & 1.23 & 5996 & \end{array}$

Table 7. Activity Switches and Distinct Activities by Age, ATUS 2003 (per Representative Day)*

\title{
Switches
}

$<55 \quad 55-59 \quad 60-64 \quad 65-69 \quad 70-74 \quad 75+$

Unadjusted means

$\begin{array}{llllll}19.72 & 18.83 & 19.29 & 18.90 & 18.46 & 17.77 \\ (0.07) & (0.20) & (0.25) & (0.25) & (0.26) & (0.18)\end{array}$

Regression estimates

$\begin{array}{lllll}-0.169 & 0.461 & 0.164 & -0.257 & -0.877\end{array}$

Distinct Activities (NACTS)

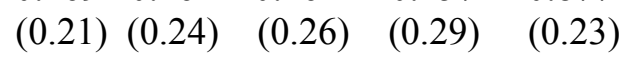
Unadjusted means
$\begin{array}{llllll}12.12 & 11.81 & 11.83 & 11.54 & 11.40 & 11.02\end{array}$
$\begin{array}{llllll}(0.04) & (0.11) & (0.13) & (0.13) & (0.14) & (0.10)\end{array}$
Regression Estimates
$\begin{array}{lllll}-0.155 & 0.042 & -0.068 & -0.308 & -0.697\end{array}$
(0.111) (0.128) (0.137) (0.151) (0.117)

\begin{abstract}
*Standard errors in parentheses. The estimates in all tables are weighted to reflect equal numbers of observations on each of the seven days of the week. The regression estimates are from an equation that also includes each person's distribution of time across market work, secondary activities and tertiary activities. It also includes the same sets of indicators and continuous variables that are included in the regressions underlying the results in Table 3 as well as a vector of indicators of educational attainment.
\end{abstract}


Table 8. Switching Activities in Relation to Time Allocation, ATUS 2003 (per Representative Day)*

\begin{tabular}{|c|c|c|c|c|c|}
\hline \multirow[b]{2}{*}{ WORK } & \multicolumn{2}{|r|}{ ALL DAYS } & \multicolumn{3}{|c|}{ WEEKDAYS WEEKENI } \\
\hline & & $\begin{array}{l}5.885 \\
(0.213)\end{array}$ & $\begin{array}{l}-0.304 \\
(0.111)\end{array}$ & $\begin{array}{l}-0.324 \\
(0.168)\end{array}$ & $\begin{array}{l}-0.498 \\
(0.136)\end{array}$ \\
\hline Minutes of Work & $\begin{array}{l}-0.0013 \\
(0.0003)\end{array}$ & $\begin{array}{l}-0.0102 \\
(0.0004)\end{array}$ & $\begin{array}{c}0.0084 \\
(0.0002)\end{array}$ & $\begin{array}{l}0.0002 \\
(0.0003)\end{array}$ & $\begin{array}{c}0.0016 \\
(0.0003)\end{array}$ \\
\hline $\begin{array}{l}\text { Minutes of Secondary } \\
\text { Activity }\end{array}$ & $\begin{array}{c}0.0107 \\
(0.0003)\end{array}$ & $\begin{array}{l}0.0105 \\
(0.0003)\end{array}$ & $\begin{array}{c}0.0010 \\
(0.0002)\end{array}$ & $\begin{array}{c}0.0009 \\
(0.0003)\end{array}$ & $\begin{array}{c}0.0008 \\
(0.0002)\end{array}$ \\
\hline $\begin{array}{l}\text { Minutes of Tertiary } \\
\text { Activity }\end{array}$ & $\begin{array}{l}-0.0073 \\
(0.0004)\end{array}$ & $\begin{array}{l}-0.0077 \\
(0.0004)\end{array}$ & $\begin{array}{l}-0.0001 \\
(0.0002)\end{array}$ & $\begin{array}{l}-0.0003 \\
(0.0003)\end{array}$ & $\begin{array}{c}0.0007 \\
(0.0003)\end{array}$ \\
\hline NACTS & & & $\begin{array}{l}1.736 \\
(0.078)\end{array}$ & $\begin{array}{l}1.825 \\
(0.115)\end{array}$ & $\begin{array}{l}1.538 \\
(0.104)\end{array}$ \\
\hline NACTS $^{2}$ & & & $\begin{array}{l}-0.0189 \\
(0.0056)\end{array}$ & $\begin{array}{l}-0.0259 \\
(0.0081)\end{array}$ & $\begin{array}{c}-0.0039 \\
(0.0080)\end{array}$ \\
\hline $\mathrm{NACTS}^{3}$ & & & $\begin{array}{c}0.0007 \\
(0.0001)\end{array}$ & $\begin{array}{c}0.0008 \\
(0.0002)\end{array}$ & $\begin{array}{c}0.0003 \\
(0.0002)\end{array}$ \\
\hline $\mathrm{R}^{2}$ & 0.199 & 0.228 & 0.798 & 0.800 & 0.791 \\
\hline $\mathrm{N}=$ & 20701 & 20701 & 20701 & 10207 & 10494 \\
\hline
\end{tabular}

*The same variables are included here as in the regressions described in the second and fourth rows of Table 7. 
Figure 1a: Fraction Doing Market Work by Age, Qtr. Hours (means with 95\% confidence intervals)

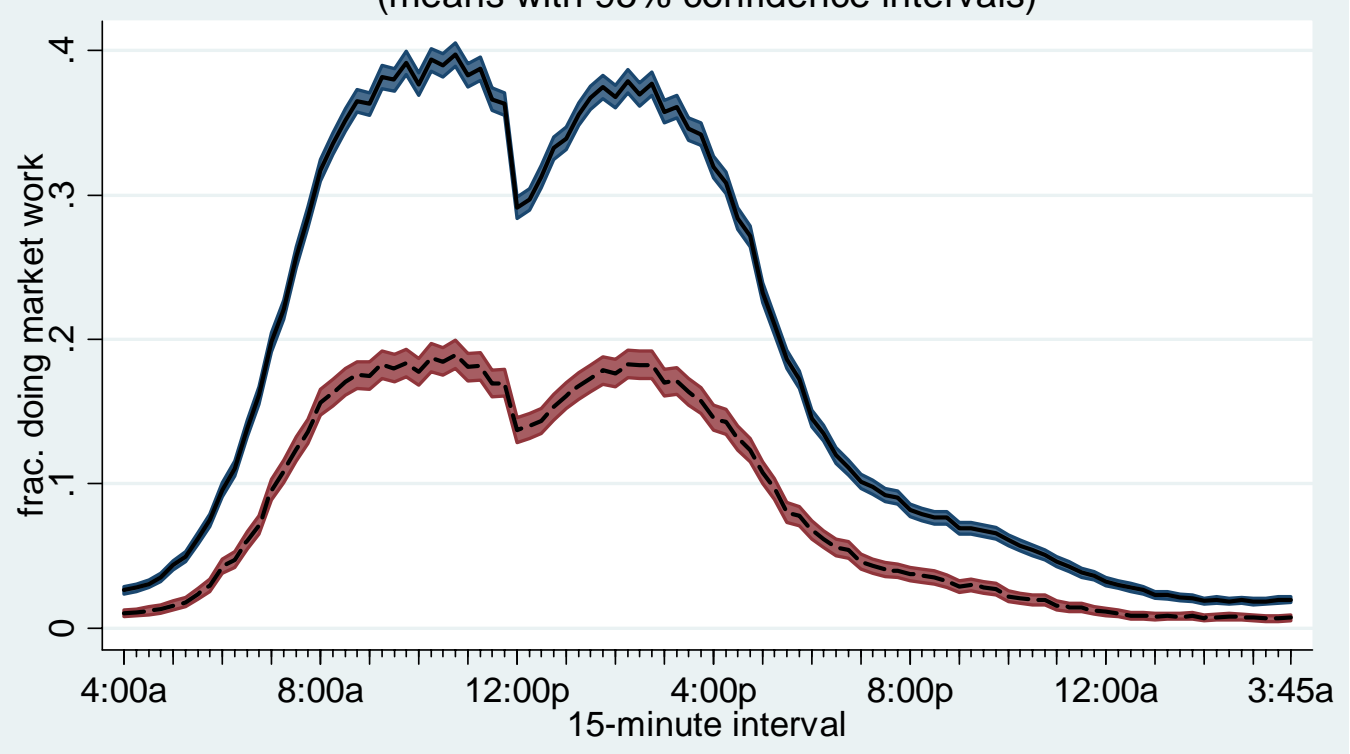

under 55 (blue) - ---- 55 and over (red)

Figure 1b: Fraction Doing Secondary Activities by Age, Qtr. Hrs.

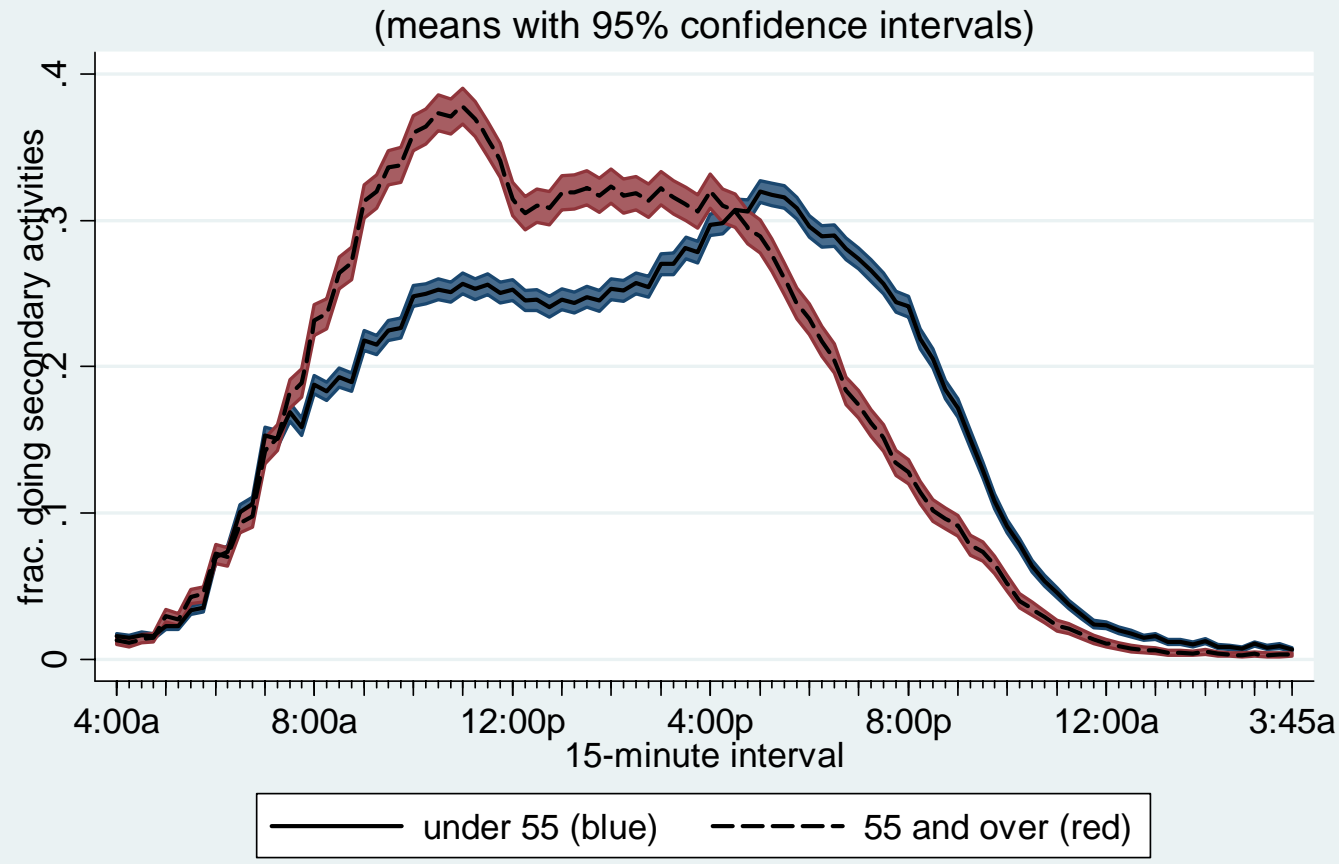


Figure 1c: Fraction Doing Tertiary Activities by Age, Qtr. Hours (means with 95\% confidence intervals)

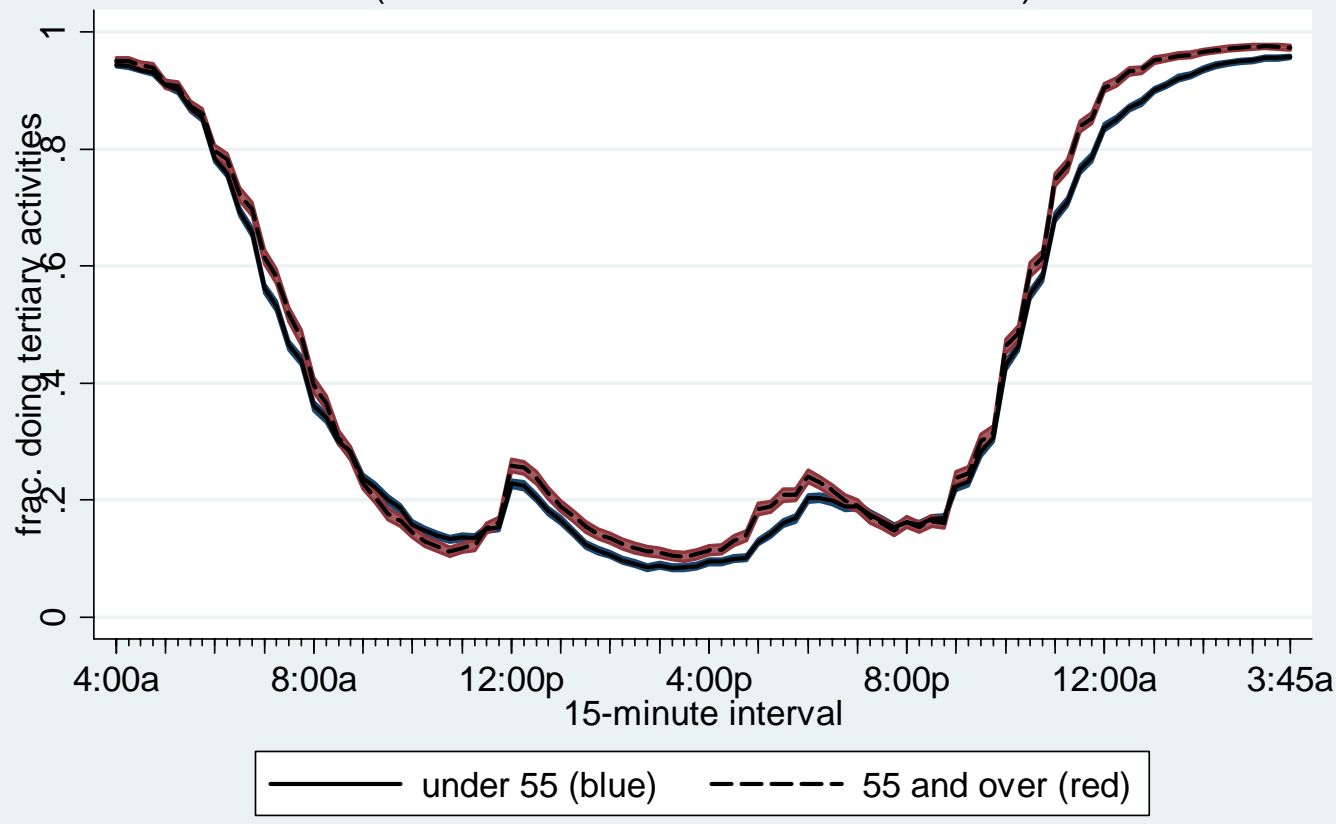

Figure 1d: Fraction Doing Leisure Activities by Age, Qtr. Hours (means with 95\% confidence intervals)

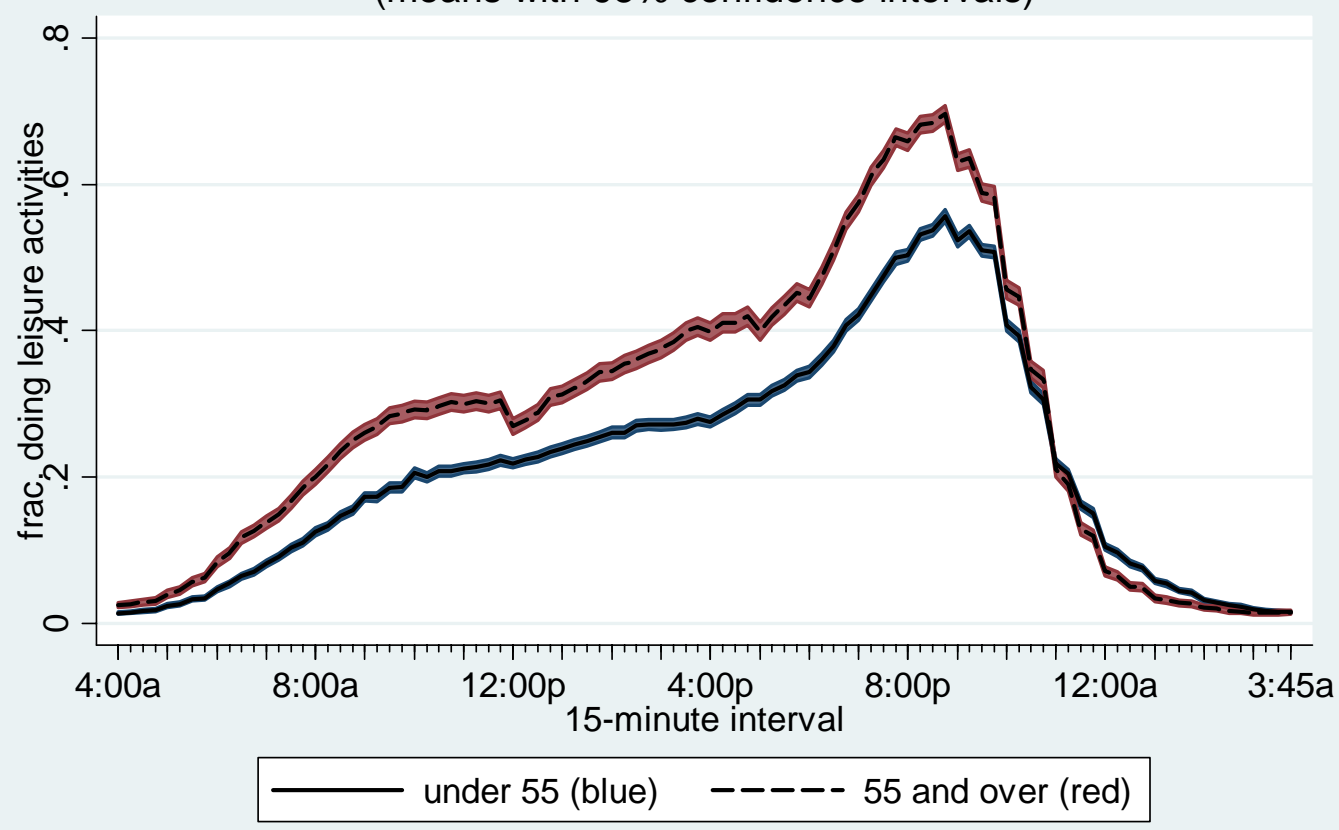


Figure 2a: Fraction Doing Secondary Activities Who Don't Work by age and quarter hours (means with 95\% confidence intervals)

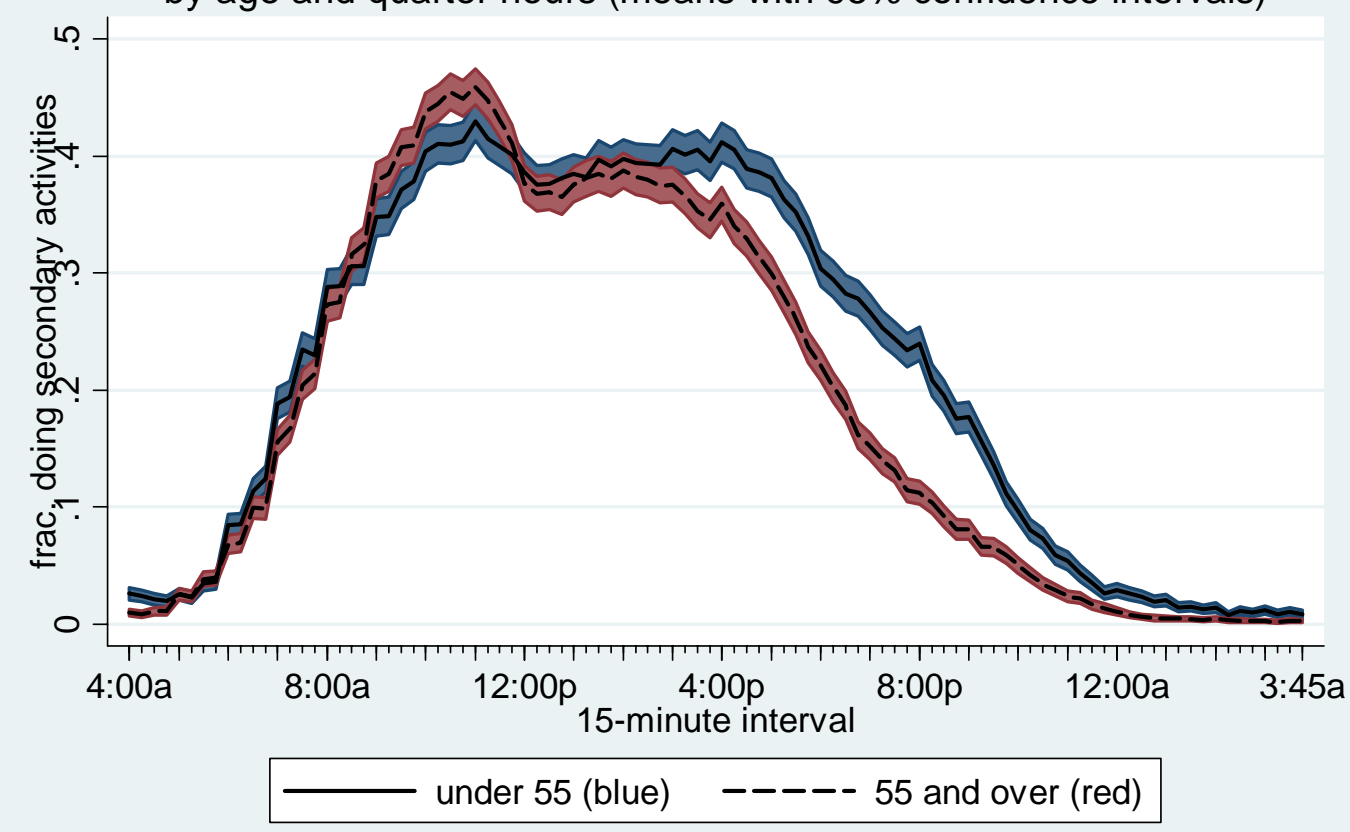

Figure 2b: Fraction Doing Tertiary Activities Who Don't Work by age and quarter hours (means with 95\% confidence intervals)

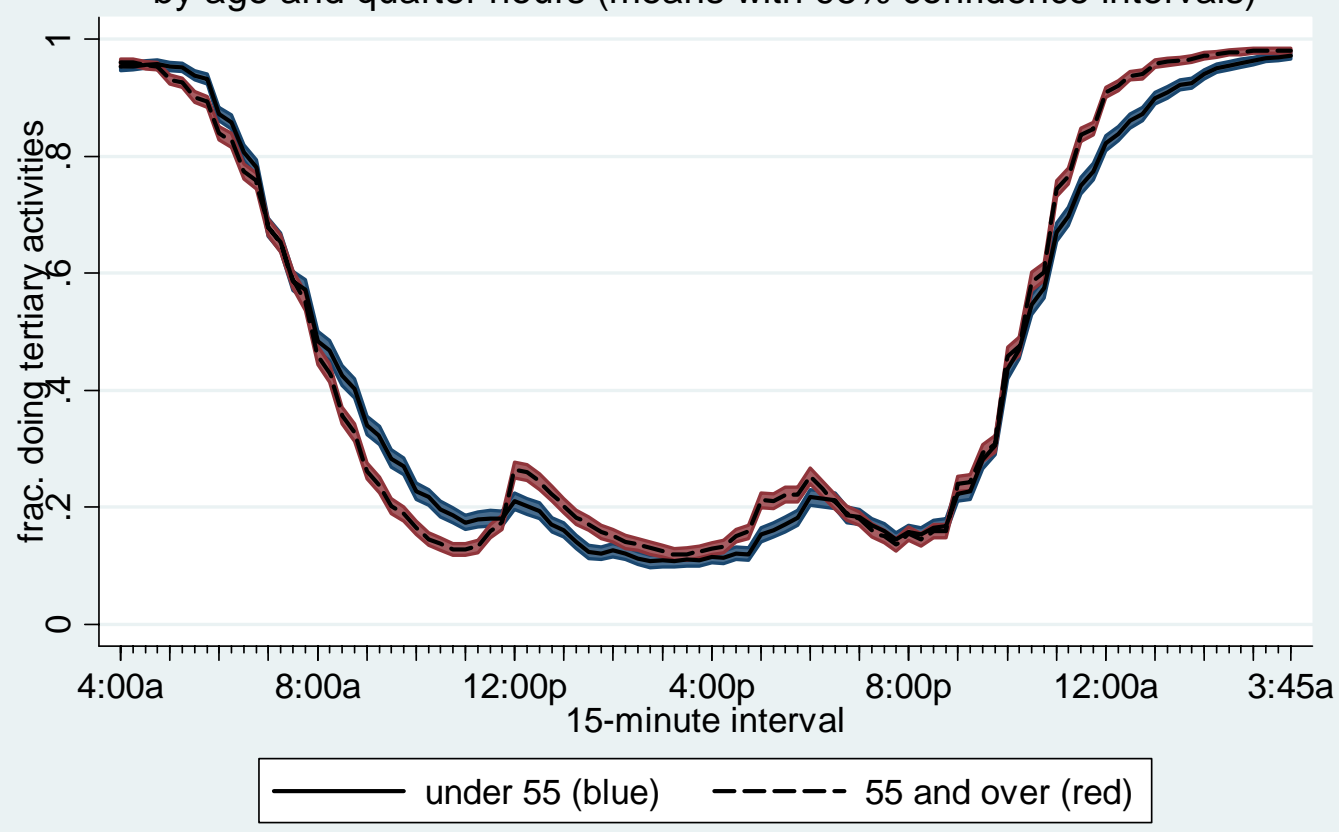


Figure 2c: Fraction Doing Leisure Activities Who Don't Work by age and quarter hours (means with 95\% confidence intervals)

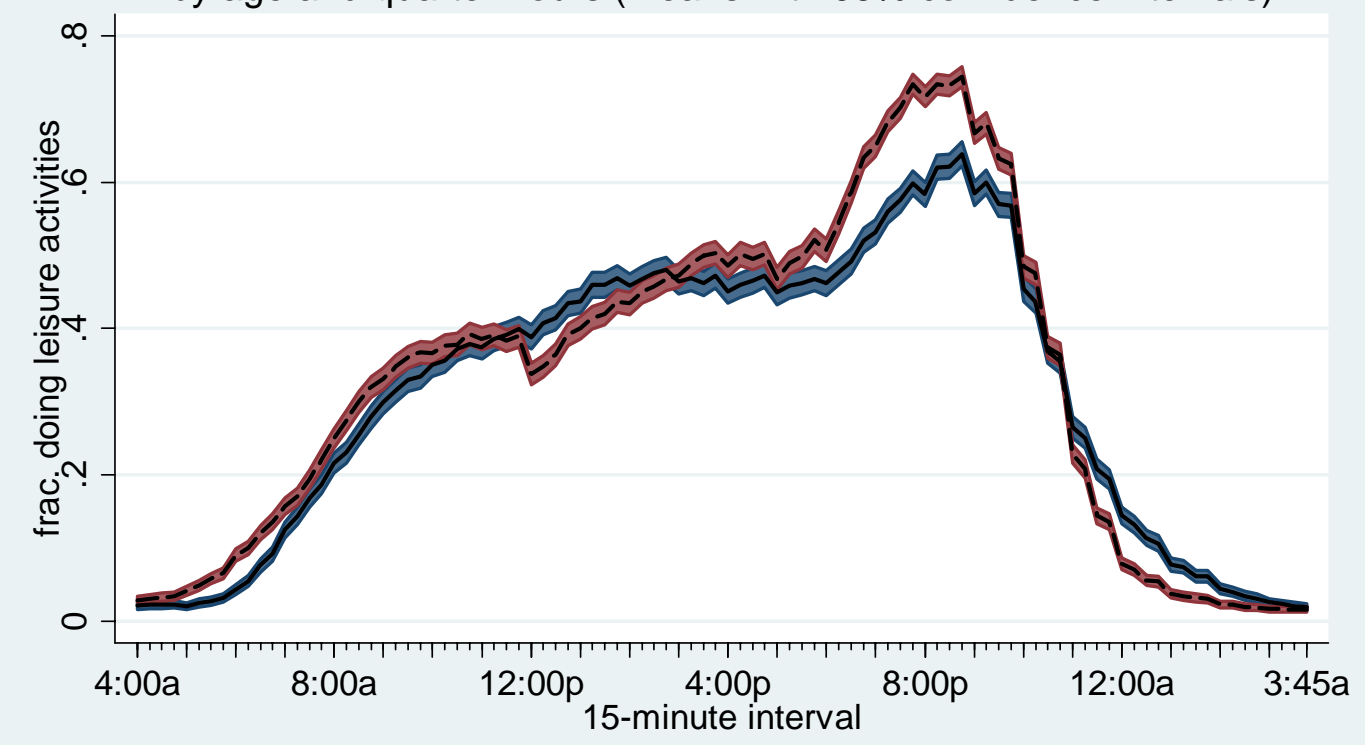

under 55 (blue) - - - - 55 and over (red) 
Figure 3a: Effect of Older Age on Market Work by age and quarter hours (est. coef. with $95 \%$ confidence intervals)

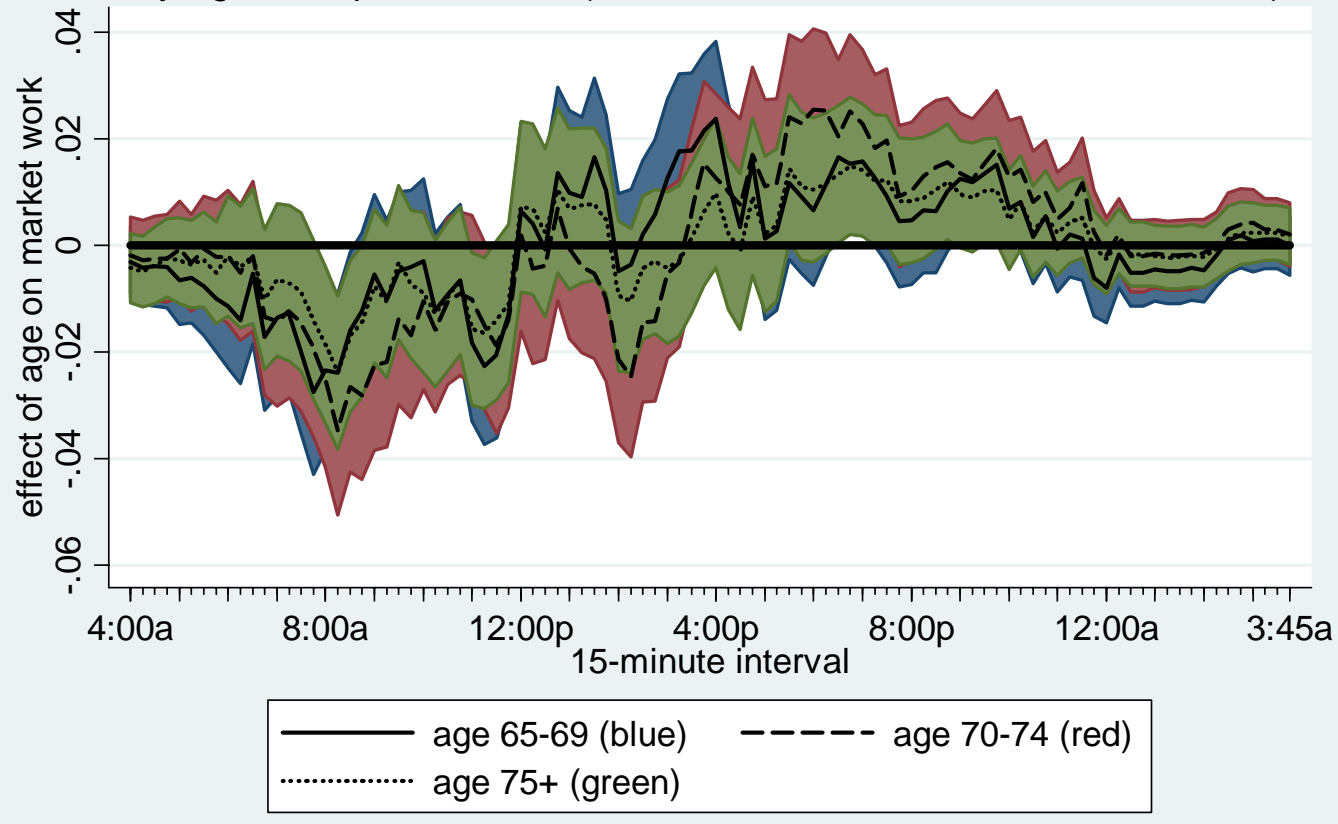

Figure 3b: Effect of Older Age on Secondary Activities by age and quarter hours (est. coef. with $95 \%$ confidence intervals)

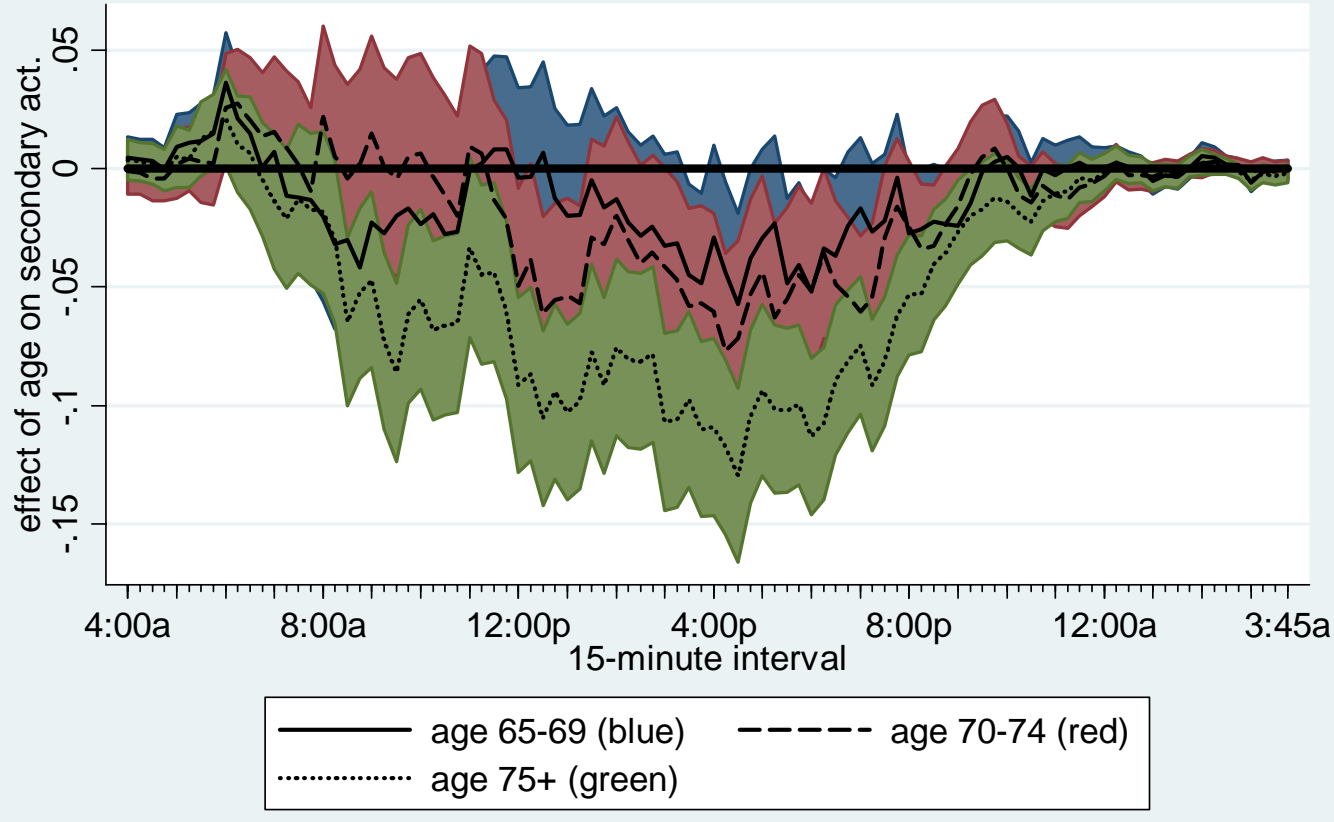


Figure 3c: Effect of Older Age on Tertiary Activities

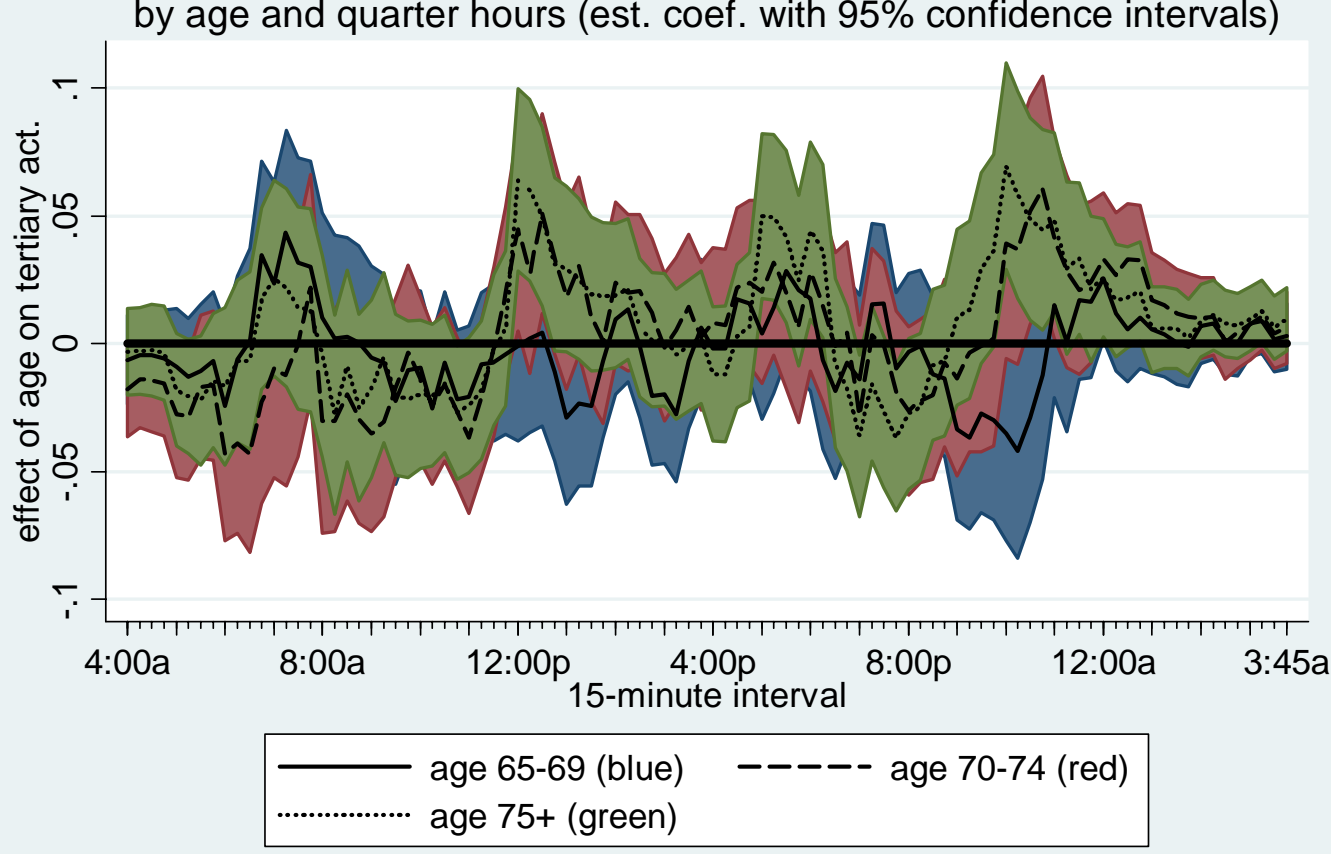

Figure 3d: Effect of Older Age on Leisure Activities by age and quarter hours (est. coef. with $95 \%$ confidence intervals)

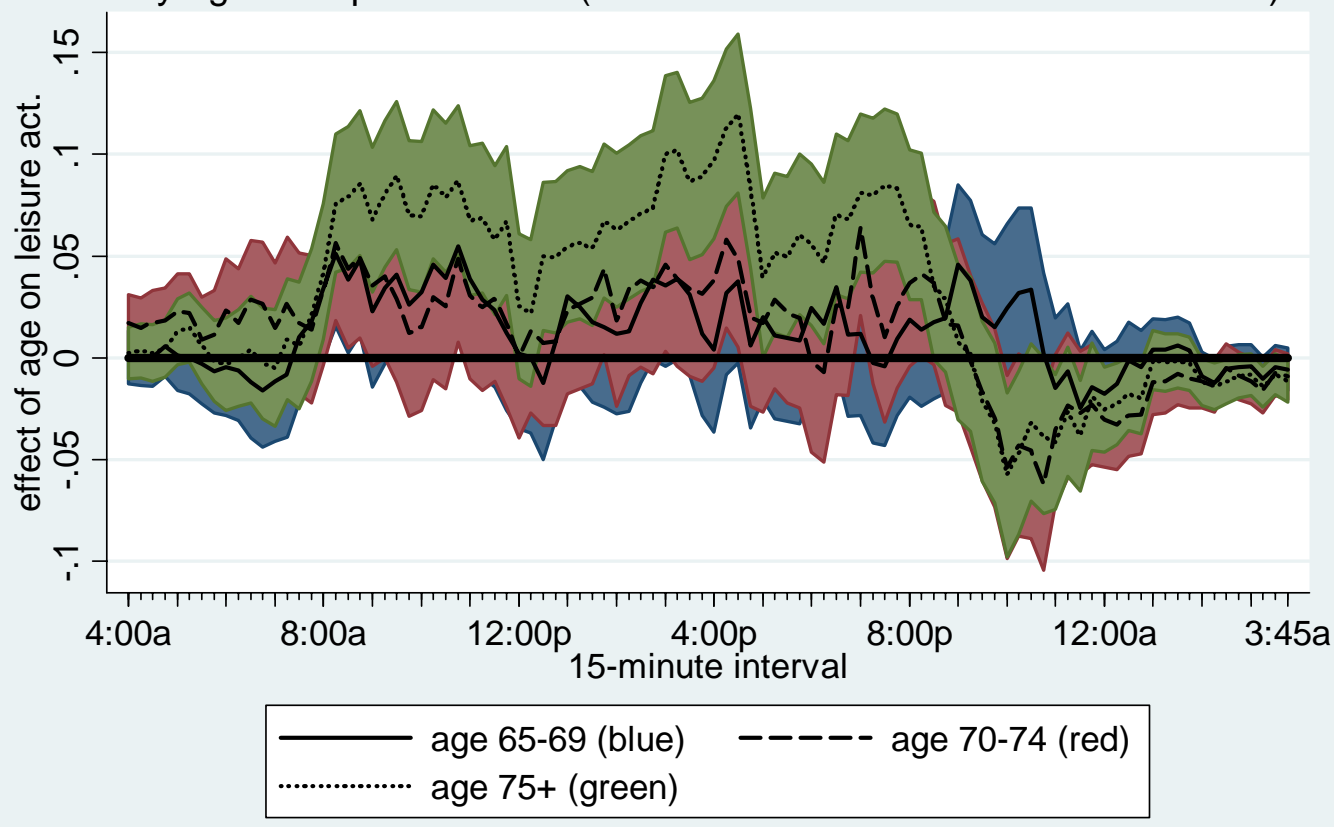



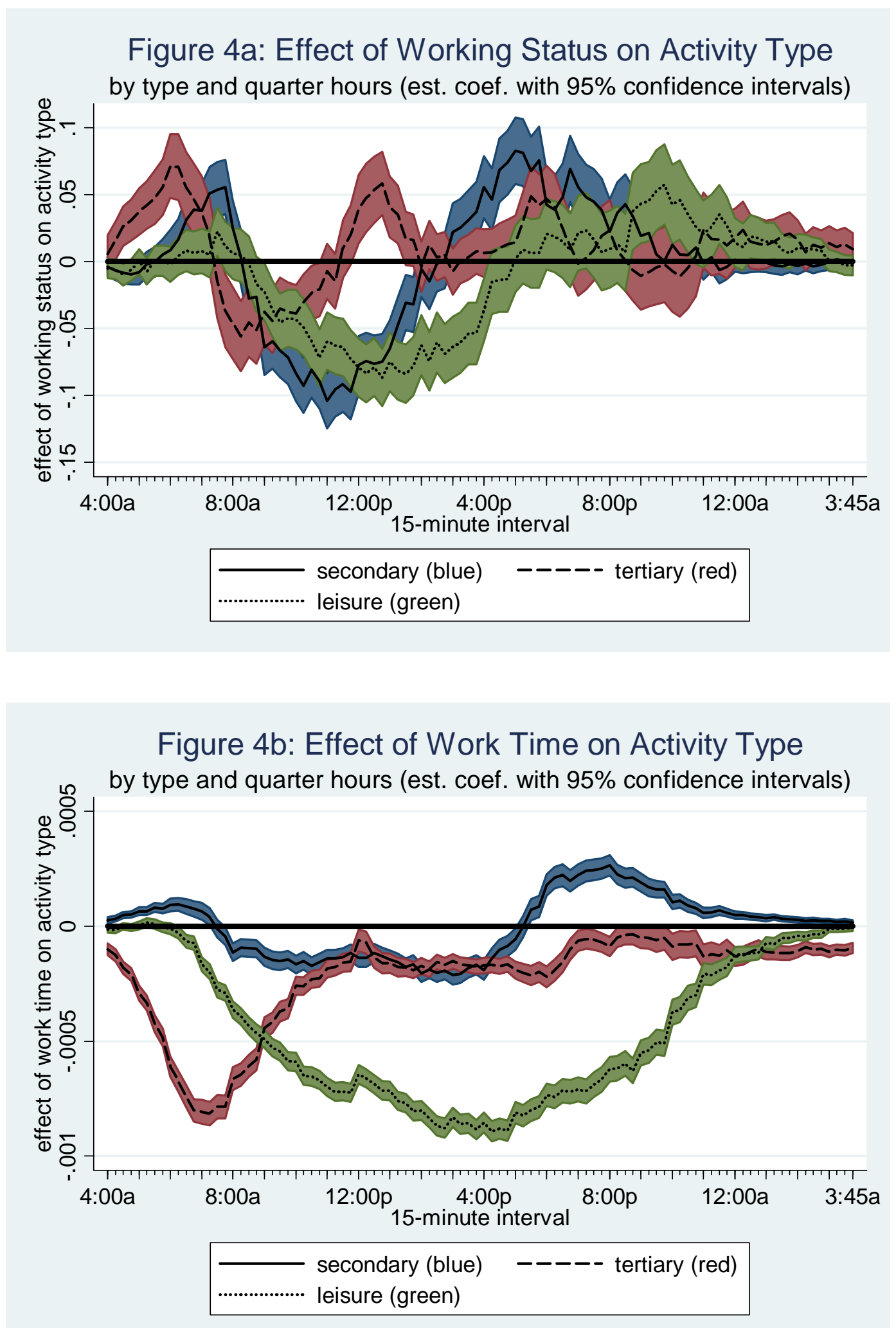
Figure 5a: Effects of Work and Fam. Inc. on Secondary Acts. by quarter hours (est. coef. with $95 \%$ confidence intervals)

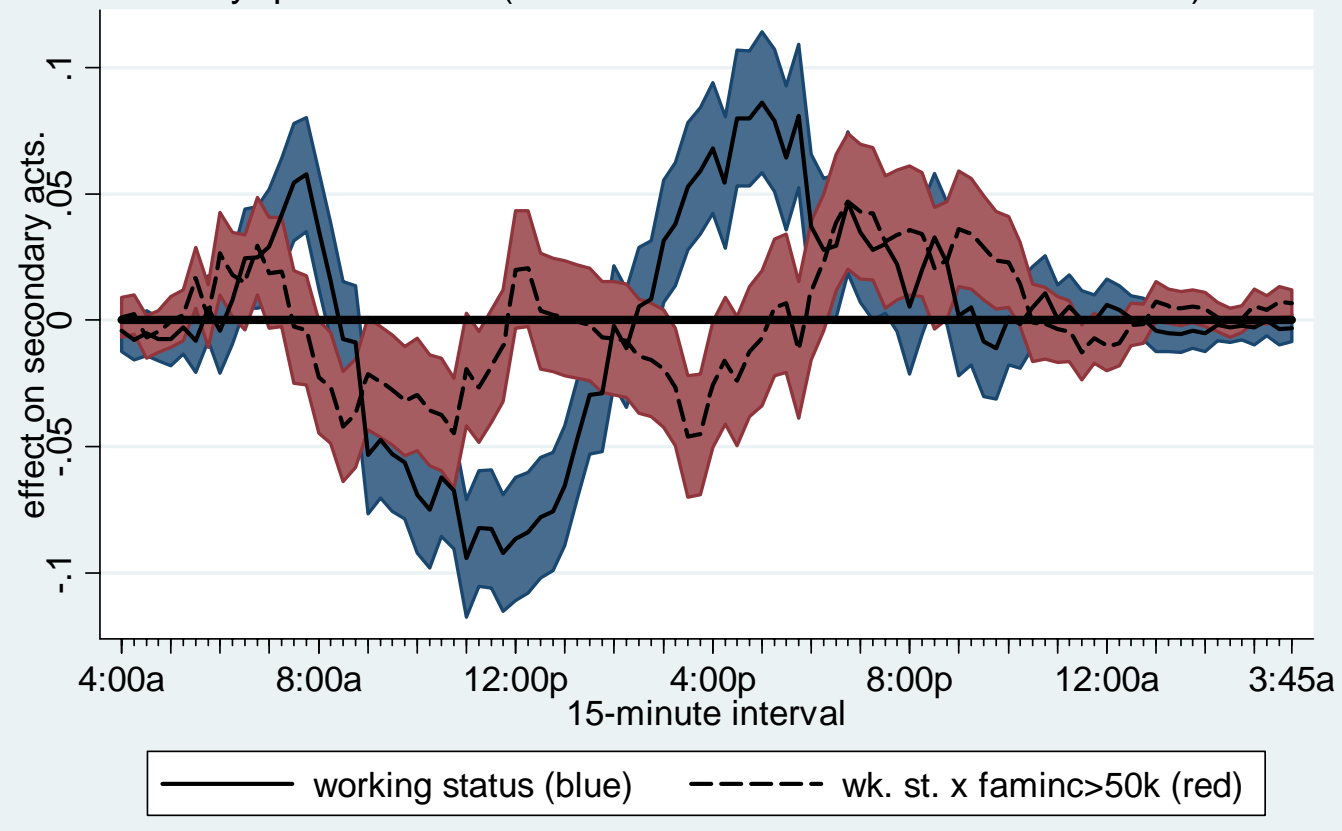

Figure 5b: Effects of Work and Fam. Inc. on Tertiary Acts. by quarter hours (est. coef. with $95 \%$ confidence intervals)

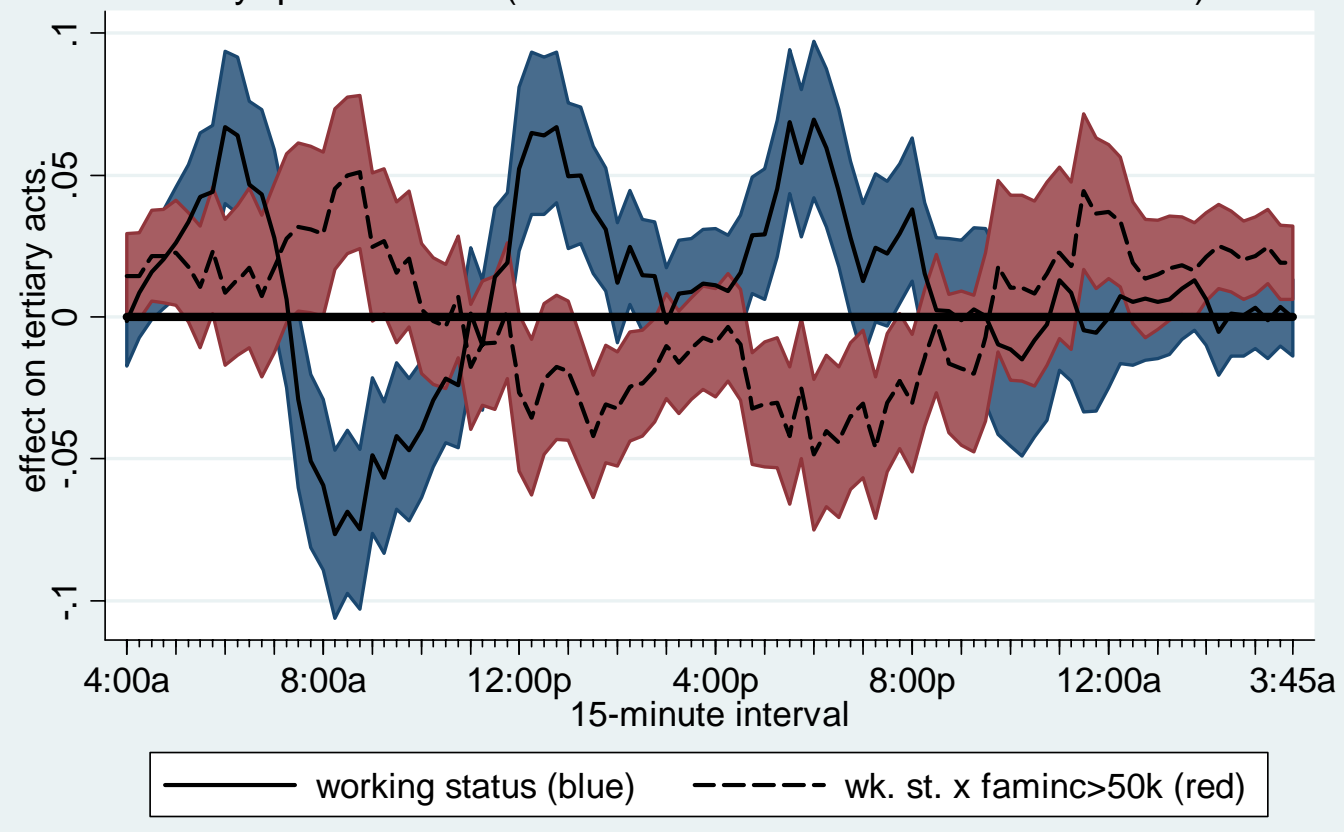


Figure 5c: Effects of Work and Fam. Inc. on Leisure Acts. by quarter hours (est. coef. with $95 \%$ confidence intervals)

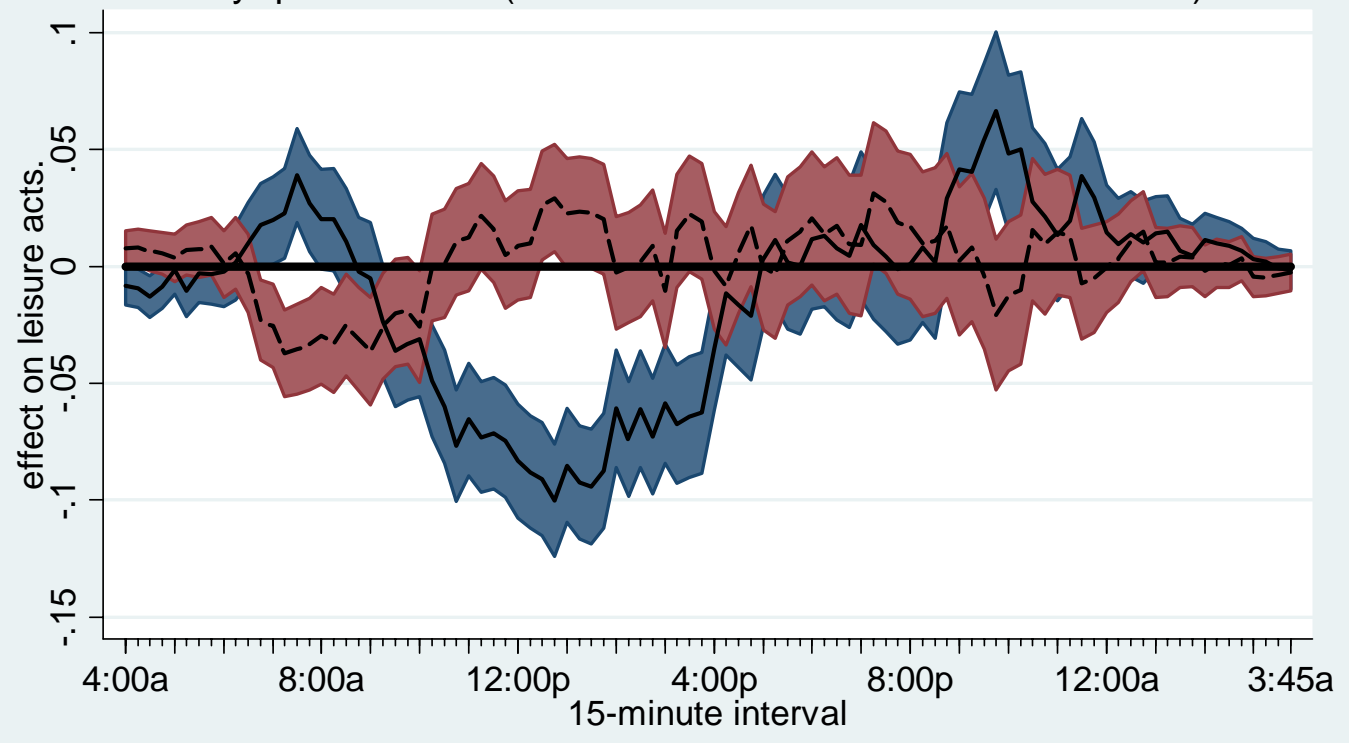

working status (blue) $\quad-----$ wk. st. $x$ faminc $>50 k$ (red) 


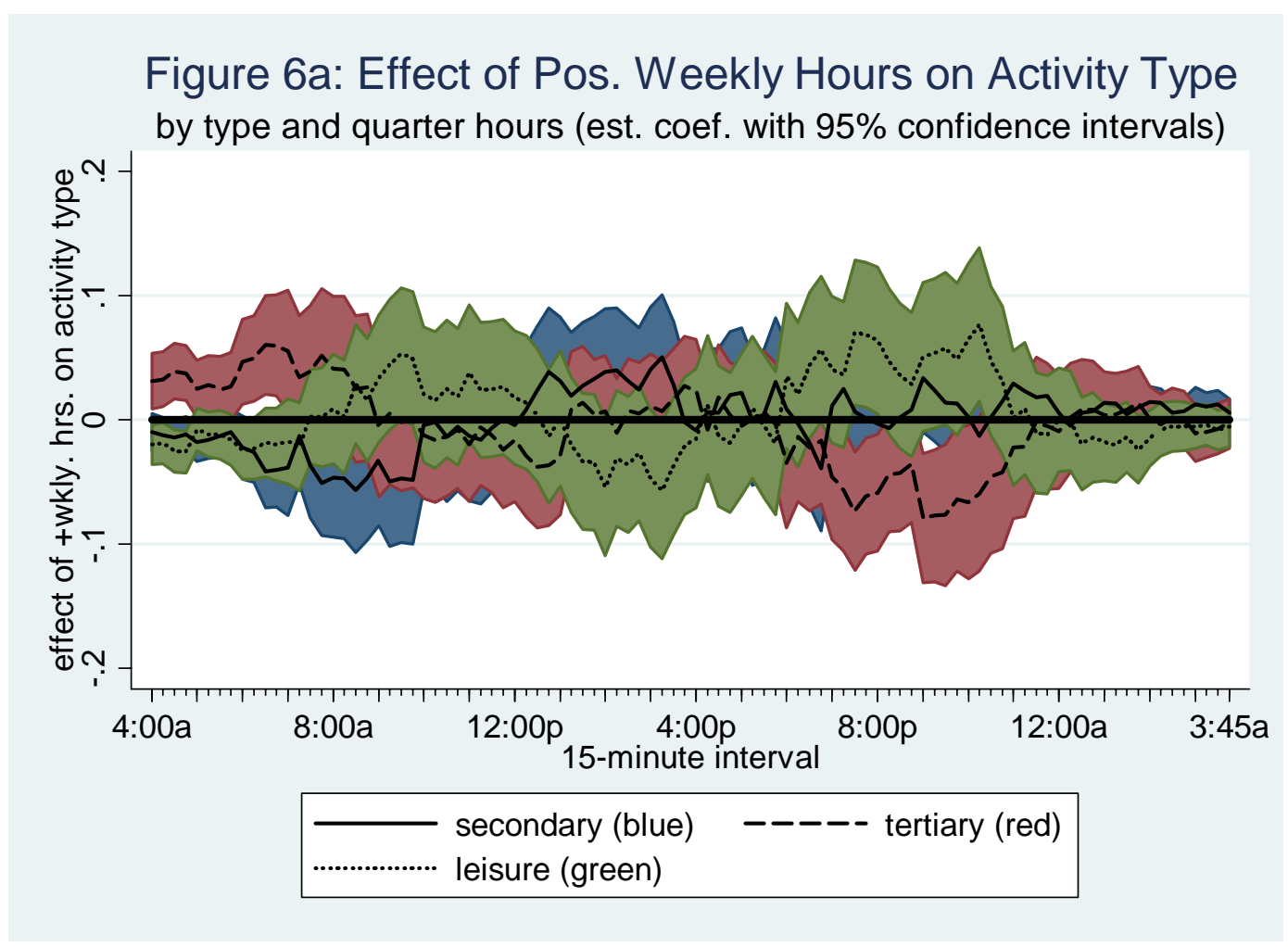

Figure 6b: Effect of Weekly Hours on Activity Type

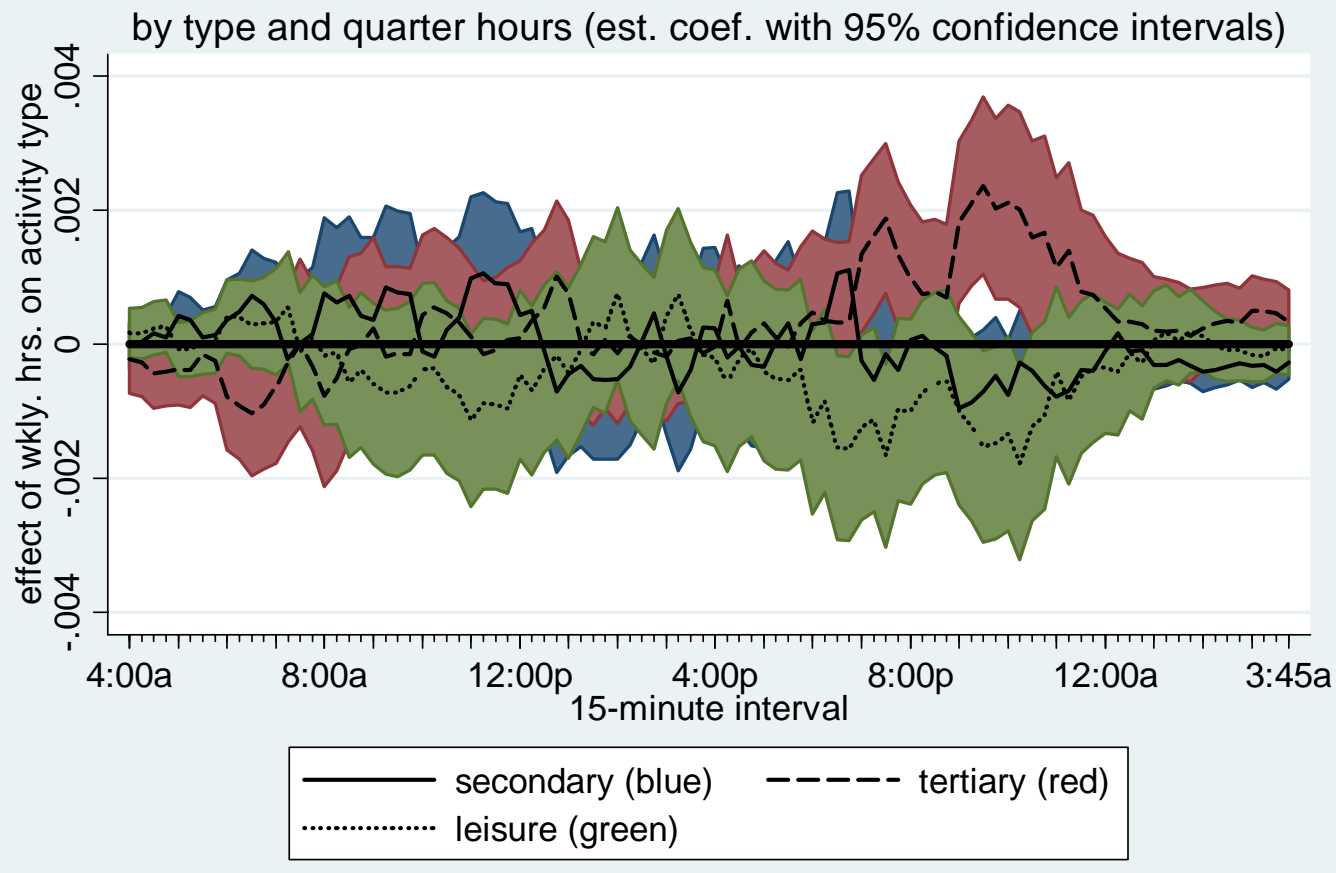

